\title{
Ozone profile retrievals from the Ozone Monitoring Instrument
}

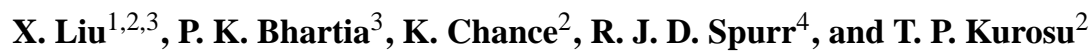 \\ ${ }^{1}$ Goddard Earth Sciences and Technology Center, University of Maryland, Baltimore County, Baltimore, Maryland, USA \\ ${ }^{2}$ Harvard-Smithsonian Center for Astrophysics, Cambridge, Massachusetts, USA \\ ${ }^{3}$ NASA Goddard Space Flight Center, Greenbelt, Maryland, USA \\ ${ }^{4}$ RT Solutions Inc., Cambridge, Massachusetts, USA
}

Received: 18 August 2009 - Published in Atmos. Chem. Phys. Discuss.: 27 October 2009

Revised: 6 February 2010 - Accepted: 24 February 2010 - Published: 12 March 2010

\begin{abstract}
Ozone profiles from the surface to about $60 \mathrm{~km}$ are retrieved from Ozone Monitoring Instrument (OMI) ultraviolet radiances using the optimal estimation technique. OMI provides daily ozone profiles for the entire sunlit portion of the earth at a horizontal resolution of $13 \mathrm{~km} \times 48 \mathrm{~km}$ for the nadir position. The retrieved profiles have sufficient accuracy in the troposphere to see ozone perturbations caused by convection, biomass burning and anthropogenic pollution, and to track their spatiotemporal transport. However, to achieve such accuracy it has been necessary to calibrate OMI radiances carefully (using two days of Aura/Microwave Limb Sounder data taken in the tropics). The retrieved profiles contain $\sim 6-7$ degrees of freedom for signal, with 5-7 in the stratosphere and $0-1.5$ in the troposphere. Vertical resolution varies from 7-11 km in the stratosphere to $10-14 \mathrm{~km}$ in the troposphere. Retrieval precisions range from $1 \%$ in the middle stratosphere to $10 \%$ in the lower stratosphere and troposphere. Solution errors (i.e., root sum square of precisions and smoothing errors) vary from $1-6 \%$ in the middle stratosphere to 6-35\% in the troposphere, and are dominated by smoothing errors. Total, stratospheric, and tropospheric ozone columns can be retrieved with solution errors typically in the few Dobson unit range at solar zenith angles less than $80^{\circ}$.
\end{abstract}

\section{Introduction}

Total ozone column and ozone profiles have been retrieved since 1970 from about a dozen Backscattered Ultraviolet (BUV) instruments that have flown on NASA and NOAA

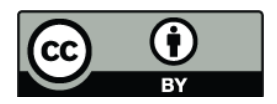

Correspondence to: $\mathrm{X}$. Liu (xliu@cfa.harvard.edu) satellites. These instruments measure at 12 discrete $1 \mathrm{~nm}$ wide wavelength bands in the $250-340 \mathrm{~nm}$ range, providing vertical information from the ozone density peak $(20-25 \mathrm{~km})$ to $\sim 50 \mathrm{~km}$ plus the ozone column down to the surface/cloud altitude (Bhartia et al., 1996). Chance et al. (1991, 1997) showed that it may be possible to extend the ozone profile information to lower altitudes, including the troposphere, by using high spectral resolution $(<0.5 \mathrm{~nm})$ hyperspectral (contiguous in wavelength) data from instruments like the Global Ozone Monitoring Experiment (GOME). Over the years, several groups, have developed physically based retrieval algorithms to retrieve ozone profiles from GOME radiances (Munro et al., 1998; Hoogen et al., 1999; Hasekamp and Landgraf, 2001; van der A et al., 2002; Liu et al., 2005). Meijer et al. (2006) evaluated ozone profiles retrieved from these algorithms and concluded that, though ozone profiles can be retrieved from GOME with better information content in the lower stratosphere than that from Solar Backscatter Ultraviolet (SBUV) instruments, they were not able to demonstrate robust determination of tropospheric ozone.

We have found that in order to derive tropospheric ozone profile it is necessary to perform accurate wavelength and radiometric calibrations and to use an accurate forward model. By making these improvements we demonstrated that valuable tropospheric ozone information can be retrieved from GOME (Liu et al., 2005, 2006a, b). In addition, by using the daily National Center for Environmental Prediction (NCEP) reanalysis tropopause fields we were able to estimate the Stratospheric Ozone Column (SOC) and Tropospheric Ozone Column (TOC), in addition to the total Ozone Column (OC).

The NASA Earth Observing System (EOS) Aura satellite was launched on 15 July 2004 into a $705-\mathrm{km}$ sunsynchronous polar orbit with a $98.2^{\circ}$ inclination and an equator-crossing time (ascending node) of $\sim 13: 45$

Published by Copernicus Publications on behalf of the European Geosciences Union. 
(Schoeberl et al., 2006). It carries four instruments, including the Ozone Monitoring Instrument (OMI), to make comprehensive measurements of stratospheric and tropospheric composition. OMI is a Dutch-Finnish built nadir-viewing pushbroom UV/visible instrument that measures backscattered radiances in three channels covering the $270-500 \mathrm{~nm}$ wavelength range (UV-1: $270-310 \mathrm{~nm}, \mathrm{UV}-2$ : $310-365 \mathrm{~nm}$, visible: $350-500 \mathrm{~nm}$ ) at spectral resolution of $0.42-0.63 \mathrm{~nm}$ (Levelt et al., 2006). OMI has a very wide field-of-view $\left(114^{\circ}\right)$ with a cross-track swath width of $2600 \mathrm{~km}$. Measurements across the track are binned into 60 positions for the UV-2 and visible channels and into 30 positions for the UV-1 channel (larger bins due to weaker signals). This results in daily global coverage with a spatial resolution of $13 \mathrm{~km} \times 24 \mathrm{~km}$ (along $\times$ across track) at nadir position for $\mathrm{UV}-2$ and visible channels and $13 \mathrm{~km} \times 48 \mathrm{~km}$ for the UV-1 channel.

Since OMI measurements are similar to GOME, except for the large swath width and much improved spatial resolution, we apply a modified GOME algorithm to OMI data. It should be noted that there is an operational OMI ozone profile algorithm (van Oss et al., 2001) developed at the Royal Netherlands Meteorological Institute (KNMI). The KNMI algorithm is similar to our algorithm overall; it also uses the optimal estimation technique to retrieve ozone profile from radiances in the spectral region $270-330 \mathrm{~nm}$. But it differs significantly from our algorithm in the implementation (e.g., using different radiometric calibration, a priori covariance matrix, radiative transfer model, retrieved variables, vertical grid).

We will present the retrieval algorithm and validation of the retrievals in several papers. The present paper describes the retrieval algorithm and its key characteristics (e.g., vertical resolution, random-noise and smoothing errors). In the second paper (Liu et al., 2010), we have validated the retrievals against the Microwave Limb Sounder (MLS) on Aura to demonstrate that stratospheric ozone profiles can be retrieved accurately from OMI, and SOC can be retrieved from OMI with solution errors comparable to or smaller than those from MLS. MLS is the first limb-viewing instrument to provide accurate estimates of SOC, for it is less affected by ice clouds than the visible and IR instruments. In separate papers, we will validate our retrievals against ozonesonde observations and OMI/MLS tropospheric ozone columns (Schoeberl et al., 2007) as well as operational total ozone products.

The present paper is organized as follows: the retrieval algorithm is described in Sect. 2. Section 3 discusses the retrieval characterization of OMI retrievals. Since the capability to measure boundary layer ozone from satellites is important for future air quality missions, in Sect. 4 we discuss future strategies for improving these retrievals. Section 5 compares OMI retrieval characteristics with those of SBUV and GOME retrievals. Section 6 shows examples of OMI retrievals with a focus on tropospheric ozone.

\section{OMI ozone profile retrieval algorithm}

\subsection{Inversion technique}

Our retrieval algorithm, initially developed for GOME (Liu et al., 2005), is based on the optimal estimation technique (Rodgers, 2000). It simultaneously and iteratively minimizes the differences between observed and simulated radiance spectra and between retrieved $(\boldsymbol{X})$ and a priori $\left(\boldsymbol{X}_{a}\right)$ state vectors, constrained by measurement error covariance matrix $\left(\mathbf{S}_{\mathrm{y}}\right)$ and a priori covariance matrix $\left(\mathbf{S}_{a}\right)$. The cost function $\chi^{2}$ to be minimized can be written:

$$
\begin{aligned}
\chi^{2} & =\left\|\mathbf{S}_{y}^{-\frac{1}{2}}\left\{\mathbf{K}_{i}\left(\boldsymbol{X}_{i+1}-\boldsymbol{X}_{i}\right)-\left[\boldsymbol{Y}-\boldsymbol{R}\left(\boldsymbol{X}_{i}\right)\right]\right\}\right\|_{2}^{2} \\
& +\left\|\mathbf{S}_{a}^{-\frac{1}{2}}\left(\boldsymbol{X}_{i+1}-\boldsymbol{X}_{a}\right)\right\|_{2}^{2} .
\end{aligned}
$$

$\boldsymbol{X}_{i+1}$ and $\boldsymbol{X}_{i}$ are the current and previous state vectors, respectively. They consist of ozone column density in a number of atmospheric layers and other auxiliary parameters (which will be described in Sect. 2.5). $\boldsymbol{Y}$ is the measurement vector, in our case the logarithm of the sun-normalized radiances. $\boldsymbol{R}$ is the forward model and the $\boldsymbol{R}\left(\boldsymbol{X}_{i}\right)$ are the $\log$ arithm of sun-normalized radiances simulated with $\boldsymbol{X}_{i} . \mathbf{K}_{i}$ is the Fréchet derivative or weighting function matrix, defined as $\partial \boldsymbol{R} / \partial \boldsymbol{X}_{i}$. The a posteriori solution is given as:

$$
\begin{aligned}
\boldsymbol{X}_{i+1} & =\boldsymbol{X}_{i}+\left(\mathbf{K}_{i}^{T} \mathbf{S}_{y}^{-1} \mathbf{K}_{i}+\mathbf{S}_{a}^{-1}\right)^{-1}\left\{\mathbf{K}_{i}^{T} \mathbf{S}_{y}^{-1}\left[\boldsymbol{Y}-\boldsymbol{R}\left(X_{i}\right)\right]\right. \\
& \left.-\mathbf{S}_{a}{ }^{-1}\left(\boldsymbol{X}_{i}-\boldsymbol{X}_{a}\right)\right\} .
\end{aligned}
$$

The main keys to successful retrievals are accurate calibration and simulation of the measurements. This is especially critical for tropospheric ozone retrievals since separation of stratospheric and tropospheric $\mathrm{O}_{3}$ requires better than 0.2 $0.3 \%$ accuracy in measuring and modeling the radiances in the Huggins band (310-340 nm) (Munro et al., 1998).

\subsection{Adaptation of the GOME algorithm to OMI}

For GOME, we performed several radiometric and wavelength calibrations to deal with calibration issues in the spectral region of our interest (Liu et al., 2005). We derived wavelength-dependent slit widths for convolution of highresolution spectroscopic data and corrected wavelengthdependent wavelength shifts. Because GOME spectra are not Nyquist-sampled, errors occur when interpolating solar irradiance to the radiance wavelength grid. We performed an undersampling correction to the spectral sampling in GOME (Chance et al., 2005; Liu et al., 2005). Due to the relative intensity offset between GOME band $1(<312 \mathrm{~nm})$ and GOME band $2(>312 \mathrm{~nm})$ and different degrees of degradation, we fitted a wavelength-dependent correction in band 1 constrained by the measurements from band 2. Finally, we optimized the fitting windows $(290-307 \mathrm{~nm}, 326-339 \mathrm{~nm})$ and 
avoided spectral regions with significant calibration problems; the spectral region $307-325 \mathrm{~nm}$ is significantly affected by inadequate polarization correction to GOME radiances and variable slit widths, while wavelengths below $290 \mathrm{~nm}$ contain large measurement errors. To accurately simulate the measurements, we used the LInearized Discrete Ordinate Radiative Transfer model (LIDORT) (Spurr, 2002) with a look-up table to correct for large radiance errors due to the neglect of polarization in the radiance calculation, and we modeled the Ring effect directly using a single scattering model (Sioris and Evans, 2000). We also improved the forward model inputs of temperature, surface pressure, surface albedo, clouds, and aerosols. With these improvements in GOME calibrations and forward model calculations, the fitting residuals in the Huggins bands were reduced to $\sim 0.2 \%$ (Liu et al., 2005), and later to $\sim 0.1 \%$ with a further set of improvements (Liu et al., 2007).

We have adapted our GOME algorithm to process OMI version 3 level $1 \mathrm{~b}$ data. The OMI instrument differs from GOME in many important ways: GOME optics is polarization sensitive, OMI uses a depolarizer; GOME mechanically scans and measures radiances from cross-track pixels using the same detector elements, OMI images the cross-track pixels onto different detector elements; OMI has much wider swath than GOME (Dobber et al., 2006; Levelt et al., 2006). These factors present somewhat different calibration and forward model challenges. The version of LIDORT used in the GOME algorithm includes a pseudo-spherical correction for the solar beam, but not for the line of sight direction. Failure to account for the Earth's curvature can lead to radiance errors of $5-10 \%$ for viewing zenith angles in the range $55-70^{\circ}$ (Spurr, 2004). In addition, the previously used look-up table for polarization correction is not accurate for large viewing zenith angles. Therefore, we now use the most recent version of Vector LIDORT (VLIDORT) (Spurr, 2006) and use a different approach to perform polarization correction, as described in Sect. 2.4.

\subsection{OMI measurements and calibrations}

Because OMI uses a polarization scrambler to depolarize the measurement signal, and the instrumental slit function only exhibits small spectral variation, OMI radiances over 307$325 \mathrm{~nm}$ are much easier to model than GOME radiances. Therefore, we choose a different fitting window for OMI, 270-310 nm from UV-1 and 310-330 nm from UV-2. Due to difference in spatial resolutions between UV-1 and UV2, two UV-2 spectra are co-added to match the UV-1 spatial resolution, and therefore retrievals are done at the UV-1 spatial resolution. To speed up the retrievals (because radiance is simulated at each OMI wavelength with effective cross sections), we co-add 5 adjacent spectral pixels in UV-1 ( 2 for UV-2). Since there is no significant natural variation in the solar irradiance at the OMI wavelengths, and individual irradiance spectra measured by OMI have both short-term noise and seasonally varying errors, we use the mean solar irradiances derived from three years of OMI data (2005-2007) to normalize the earthshine radiances (adjusted for Sun-Earth distances). To account properly for OMI instrumental slit functions, we derive the slit widths from the solar irradiance spectrum separately for each channel and each cross-track position by cross-correlating the OMI irradiance spectrum to a high-resolution solar irradiance reference spectrum (Caspar and Chance, 1997; Chance, 1998), assuming a Gaussian slit function in the convolution. OMI level $1 \mathrm{~b}$ radiances include in-flight wavelength calibration, so we do not need to correct wavelength registration before the retrievals; we only fit two radiance/irradiance shift parameters (one for each channel) in the retrievals to account for residual wavelength registration errors. Compared to GOME, OMI spectral sampling is significantly improved, especially UV-2 (Chance et al., 2005). The undersampling correction implemented in GOME has only negligible effects on both fitting residuals and retrievals, so this correction is not used in the OMI algorithm. The OMI instrument has been very stable through 2008 , with degradation of $\sim 2 \%$ in UV- 1 and $\sim 1 \%$ UV-2. We do not fit a wavelength-dependent correction the UV-1 channel to account for varying intensity offsets between the two channels. In fact, doing so reduces the ozone information.

OMI uses a 2-D CCD detector array, where each crosstrack position uses a different row of detectors. All the operational level-2 products have shown across-track-dependent biases due to limited pre-launch calibration as a function of detector position. Our preliminary retrievals indicate both wavelength and cross-track position dependent errors in our fitting window. To investigate the quality of OMI radiometric calibration and perform necessary corrections to OMI radiances, we simulate OMI radiances and compare them with the observed radiances. The MLS instrument on the Aura satellite measures ozone profiles down to $215 \mathrm{hPa}$ with vertical resolution of $\sim 3 \mathrm{~km}$. Its ozone products have been extensively validated (Jiang et al., 2007; Froidevaux et al., 2008; Livesey et al., 2008). Thus, MLS provides an excellent source of ozone to check the OMI calibration. The radiance simulation is the same as that done in the first iteration of retrievals before fitting (to be described in Sect. 2.4) except that we use zonal mean v2.2 MLS ozone profiles for pressure $<215 \mathrm{hPa}$, and climatological ozone profiles from McPeters et al. (2007) for pressure $>215 \mathrm{hPa}$. We examine the average differences between simulated and observed radiances over the tropics, where there is less spatiotemporal variability in ozone.

Figure 1 shows the mean radiance differences in the spectral range $270-350 \mathrm{~nm}$ for different UV-1 cross-track positions, derived from clear-sky conditions on 11 July 2006. The differences typically vary from $-6 \%$ to $7 \%$ and are up to $\sim 10 \%$ in $300-310 \mathrm{~nm}$ for the first and last cross-track positions. There are significant wavelength and cross-track dependencies, and there are discontinuities of 3-9\% at $310 \mathrm{~nm}$ between UV-1 and UV-2. Some of the spikes around 280 


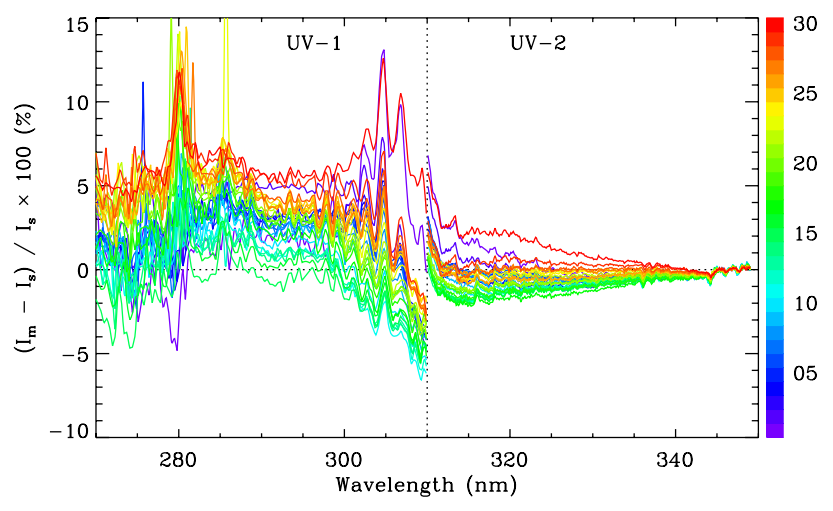

Fig. 1. Mean percentage difference (residuals) between OMI measured $\left(I_{m}\right)$ radiances and those simulated $\left(I_{S}\right)$ using MLS $\mathrm{O}_{3}$ profiles are plotted as a function of wavelength. The $30 \mathrm{UV}-1$ acrosstrack positions are shown in different colors. These residuals are derived from nearly clear-sky conditions (effective cloud fraction $<20 \%$ ) in the latitude range $0-20^{\circ} \mathrm{S}$ on 11 July 2006 . Pixels affected by aerosols (OMTO3 aerosol index greater than 1 or less than -1$)$ and sun glint are not used.

and $285 \mathrm{~nm}$ are partly due to emission from $\mathrm{Mg}^{+}$and $\mathrm{Mg}$ in the ionosphere (Joiner and Aikin, 1996), which is not included in our forward model simulation. There are some high frequency structures between $300-310 \mathrm{~nm}$ that cannot be explained either by errors in wavelength calibration or possible errors in MLS ozone profiles used in our simulation. The smaller differences at longer wavelengths are related to small errors in our cloud correction algorithm. The mean differences can vary by up to a few percent from day to day, especially in the wavelength range $300-315 \mathrm{~nm}$, but the overall features (i.e., wavelength and cross-track dependencies) do not change much. The standard deviations of the mean differences, not shown here, vary from 1-2\% at wavelengths shorter than $295 \mathrm{~nm}$ (except around strong solar Fraunhofer lines) and longer than $320 \mathrm{~nm}$ to $6-10 \%$ between $300-315 \mathrm{~nm}$. They are mainly determined by the zonal variability of ozone due to the use of zonal mean MLS and climatological ozone profiles.

Although forward model parameter errors in the simulation (e.g., errors in MLS and climatological ozone) can contribute to some of the differences shown in Fig. 1, the presence of consistent overall features for a number of time periods indicates the existence of calibration problems in OMI level $1 \mathrm{~b}$ data. The radiances at shorter wavelengths should not depend on cloudiness. However, we find that these differences increase with increasing cloudiness, suggesting the existence of straylight errors in UV-1 and at the shorter UV2 wavelengths. Since we cannot derive good tropospheric ozone in presence of these errors, we apply a first-order correction to OMI radiances using the average percent difference between measured and simulated radiances derived from 2 days of MLS data in the tropics. This so-called "soft" (also called vicarious) calibration is applied independent of time and latitude, so our retrievals are still affected by residual straylight errors that very likely vary seasonally and latitudinally. These errors are still under investigation.

\subsection{Radiative transfer calculation}

We use the VLIDORT model to calculate radiances and weighting functions (Spurr, 2006, 2008). The model implements the complete vector discrete ordinate solution with full linearization facility (analytic weighting functions), deals with attenuation of solar and line-of-sight paths in a curved atmosphere, and includes an exact treatment of the single scatter computation. VLIDORT can be run in scalar-mode only (without polarization), which is faster by almost an order of magnitude than a vector calculation. For OMI retrievals, we adopt the following procedure to optimize radiative transfer calculations.

We perform both scalar-only and full-polarization calculations at $\sim 10$ selected wavelengths and derive polarization corrections at these wavelengths. Next, we perform scalaronly calculations at all other wavelengths, and then interpolate the polarization corrections. The radiance calculation time for the retrieval spectral window is then faster by a factor of $\sim 6$ than that achieved using VLIDORT in fullpolarization mode at all wavelengths; accuracy is maintained to better than $0.1 \%$.

The radiance calculation is made for a Rayleigh atmosphere (no aerosols) with Lambertian reflectance assumed for the surface and for clouds (treated as reflecting boundaries). For GOME, we used climatological aerosols in the retrievals (Liu et al., 2005). For OMI, we decided to switch this option off because the fitting of wavelength-dependent surface albedo in UV2 with a first-order polynomial can partly account for the presence of aerosols just like the use of climatological aerosols. In contrast to the situation with the GOME retrieval algorithm, trace gases other than ozone are not modeled and retrieved. This only slightly affects retrievals except for volcanic eruption conditions. Retrievals of $\mathrm{SO}_{2}$ and $\mathrm{BrO}$ will be added later, since there is adequate spectral information in our fitting window for these trace gases. High-resolution ozone cross sections (Brion et al., 1993), convolved with fitted OMI slit functions and weighted with a high-resolution solar reference spectrum, are used in the simulation to reduce the computation time. For radiative transfer above a reflecting cloud boundary, we take the cloud-top pressure from the $\mathrm{OMI} \mathrm{O}_{2}-\mathrm{O}_{2}$ algorithm (Acarreta et al., 2004). The monthly mean cloud climatology derived from OMI Raman cloud products (Joiner and Vasilkov, 2006) is used to fill in where cloud-top pressure is not available from the $\mathrm{O}_{2}-\mathrm{O}_{2}$ algorithm due to quality flag control. An initialized cloud fraction is determined from a single wavelength around $347 \mathrm{~nm}$ (degraded to $1.1 \mathrm{~nm}$ spectral resolution), based on surface albedo taken from an improved TOMS-derived database (O. Torres, personal communication, 2008). The cloud fraction is then retrieved as an 
auxiliary parameter. To account for the temperature dependence of ozone absorption, we use daily temperature profiles from NCEP reanalysis data (Kalnay et al., 1996). Due to the much higher spatial resolution of OMI compared with NCEP data $\left(2.5^{\circ} \times 2.5^{\circ}\right)$, we do not use the NCEP surface pressure; instead, surface pressure is derived from the topographical altitude of the OMI pixel by assuming a standard sea level pressure of $1 \mathrm{~atm}$.

In our retrievals, aerosols, clouds, and surface pressure are either not accurately known or are not modeled in the retrievals. In addition, OMI radiances are inadequately calibrated. We fit wavelength-dependent surface albedo (i.e., zero order for UV-1, first-order polynomial for UV-2) as tuning parameters to partly account for these effects.

\subsection{Retrieval scheme}

Our state vector contains partial ozone column density (in $\mathrm{DU}, 1 \mathrm{DU}=2.69 \times 10^{16}$ molecules $\mathrm{cm}^{3}$ ) in 24 layers. The 25 level vertical pressure grid is set initially at $P_{i}=2^{-i / 2}$ atm for $i=0,23$ and with the top of the atmosphere set for $P_{24}$. This pressure grid is then modified: daily NCEP thermal tropopause pressure is used to replace the level closest to it, and layers between the surface and tropopause are distributed equally with logarithmic pressure. Each layer is thus approximately $2.5-\mathrm{km}$ thick, except for the top layer. There are 4 to 7 layers in the troposphere, depending on the tropopause height. There are several different definitions of tropopause, and which tropopause to use for defining TOC is controversial (Liu et al., 2006b; Stajner et al., 2008). For the retrieval of ozone profiles, it is unnecessary to use a tropopause. The primary purpose of adjusting the model layering to tropopause height is to derive TOC and SOC; the actual value of the tropopause pressure has negligible effect on the retrieved total ozone column and ozone values at layers not affected by the layer adjustment. TOC and SOC can be re-calculated from our retrievals through interpolation if different knowledge of the tropopause is available.

Table 1 lists the fitting variables used in the retrievals, their a priori values and a priori errors. In addition to the 24 ozone values, our state vector also contains wavelengthdependent surface albedo (constant surface albedo for UV-1 and first-order polynomial for UV-2), cloud fraction, scaling parameters for the Ring effect (1 parameter for each channel), radiance/irradiance wavelength shifts (1 parameter for each channel), wavelength shifts between radiance and ozone cross sections (first-order polynomial for each channel), and scaling parameters for mean fitting residuals derived from one orbit of retrievals using all the other parameters ( 1 parameter for each channel). To constrain the retrievals, we use climatological mean ozone profiles and their standard deviations derived from 15 years of ozonesonde and Stratospheric Aerosol and Gas Experiment (SAGE) as a priori, which varies with latitude and month (McPeters et al., 2007). A correlation length of $6 \mathrm{~km}$ is used to construct the off-diagonal terms of the a priori covariance matrix. All the other parameters are assumed to be uncorrelated with each other and with ozone variables. We use OMI random-noise errors from the level $1 \mathrm{~b}$ data as measurement errors. However, fitting residuals ( $\sim 0.45 \%$ in UV- 1 and $\sim 0.07 \%$ in UV-2 on average even without fitting the mean fitting residuals) for successful retrievals are typically half the size of the measurement random-noise errors. This is due to a bug in the random-noise calculation algorithm, which overestimates the errors by the square root of co-additions (2, 4, and 5 for arctic, mid-latitude, and tropical measurements, respectively) (Braak, 2010).

In our retrievals, the selection of these parameters is based on their impact on fitting residuals, their cross-correlation with ozone variables, and comparisons with ozonesonde observations. We want to include variables that can reduce fitting residuals and improve comparison with ozonesonde observations, and at the same time to avoid variables strongly correlated with ozone variables. Of all the non-ozone parameters, the first-order wavelength dependent surface albedo term in UV2 has the most noticeable correlation (0.2-0.5) with ozone variables, especially in the troposphere. Despite its correlation with ozone, this parameter is used to account partly for aerosol, clouds, and calibration signatures, and it is very useful to reduce fitting residuals and improve retrievals. Although higher-order polynomials can further reduce fitting residuals, they can adversely impact retrieval accuracy due to overly strong correlation with ozone. In addition, the parameters for radiance/ozone cross-section wavelength shifts can have correlations of $0.2-0.3$ with ozone variables. The zeroorder shift term for UV-1 has significant values of $\sim 0.03 \mathrm{~nm}$. We found that these shifts are not due to actual wavelength registration errors in either OMI radiances or ozone cross sections, but instead to some wavelength registration artifacts introduced in our spectral coadding (values are much smaller without spectral coadding). These variables also help to improve retrievals. In general, all the other non-ozone parameters have weak correlations $(<0.2)$ with ozone variables. For non-ozone parameters themselves, there are strong correlations $(>0.5$ ) between surface albedo terms and cloud fraction, and between zero-order and first-order radiance/ozone cross-section wavelength shifts in both UV-1 and UV-2.

\section{Retrieval characterization}

\subsection{Concepts for retrieval characterization}

The Averaging Kernels (AK) matrix $\mathbf{A}$, whose $i^{\text {th }}$ row $\mathbf{A}_{i j}$ $(j=1, n$, where $n$ is the number of layers) describes about how the retrieved profile in a particular layer $i$ is affected by changes in the true profile $\boldsymbol{X}_{T}$ in all layers, characterizes the retrieval sensitivity and vertical resolution of the retrieved profile. Though it can be calculated by perturbation analysis for any type of retrieval algorithm, the optimal 
Table 1. List of fitting variables, a priori values and a priori errors. A correlation length of $6 \mathrm{~km}$ is used to construct the a priori covariance matrix for ozone variables. All the other variables are assumed to be uncorrelated with each other and with ozone varaibles.

\begin{tabular}{|c|c|c|c|}
\hline Fitting variables & \# Variables & A prior & A prior errol \\
\hline Ozone at each layer & 24 & climatology & climatology \\
\hline Surface albedo in UV-1 & 1 & climatology & 0.05 \\
\hline Surface albedo in UV-2 & 1 & climatology & 0.05 \\
\hline $\begin{array}{l}\text { First-order wavelength-dependent term for sur- } \\
\text { face albedo in UV-2 }\end{array}$ & 1 & 0.0 & 0.01 \\
\hline Cloud fraction & 1 & Derived from $347 \mathrm{~nm}$ & 0.05 \\
\hline $\begin{array}{l}\text { Ring scaling parameters } \\
\text { ( } 1 \text { for each channel) }\end{array}$ & 2 & 1.9 & 1.0 \\
\hline $\begin{array}{l}\text { Radiance/irradiance wavelength shifts (1 for } \\
\text { each channel) }\end{array}$ & 2 & 0.0 & $0.02 \mathrm{~nm}$ \\
\hline $\begin{array}{l}\text { Radiance } / \mathrm{O}_{3} \text { cross section wavelength shifts } \\
\text { (zero order, } 1 \text { for each channel) }\end{array}$ & 2 & 0.0 & $0.02 \mathrm{~nm}$ \\
\hline $\begin{array}{l}\text { Radiance } / \mathrm{O}_{3} \text { cross section wavelength shifts } \\
\text { (first order, } 1 \text { for each channel) }\end{array}$ & 2 & 0.0 & 0.004 \\
\hline $\begin{array}{l}\text { Scaling parameters for mean fitting residuals ( } 1 \\
\text { for each channel) }\end{array}$ & 2 & 1.0 & 0.6 \\
\hline
\end{tabular}

estimation retrieval technique provides a closed-form solution for A (Rodgers, 2000):

$$
\begin{aligned}
\mathbf{A} & =\frac{\partial \boldsymbol{X}}{\partial \boldsymbol{X}_{T}}=\left(\mathbf{K}^{T} \mathbf{S}_{y}^{-1} \mathbf{K}+\mathbf{S}_{a}^{-1}\right)^{-1} \mathbf{K}^{T} \mathbf{S}_{y}^{-1} \mathbf{K}=\hat{\mathbf{S}} \mathbf{K}^{T} \mathbf{S}_{y}^{-1} \mathbf{K} \\
& =\mathbf{G K}
\end{aligned}
$$

where $\hat{\mathbf{S}}$ is the solution error covariance matrix, and $\mathbf{G}$ is the matrix of contribution functions. The diagonal elements of $\mathbf{A}$, known as Degrees of Freedom for Signal (DFS), describe the number of useful independent pieces of information available at each layer from the measurements. The trace of $\mathbf{A}$ is the total DFS for the retrieval. Similarly, the sum of the diagonal elements in the troposphere (stratosphere) is the tropospheric (stratospheric) DFS. The AKs for OC, SOC, and TOC can be derived from $\mathbf{A}$ by summing up the rows of $\mathbf{A}$ in all, stratospheric, and tropospheric layers, respectively. To avoid confusion, we will call those AKs as Column Averaging Kernels $(\mathrm{CAK})$ or $\mathbf{A}_{c}$. The OC CAK represents the fraction of actual ozone columns deviating from the climatology at individual layers that can be retrieved in the entire profile. Therefore, it is essentially the same quantity as the Retrieval Efficiency (RE) (Hudson et al., 1995), an important concept for OC retrievals because it indicates what fraction of ozone in the lower troposphere or boundary layer can be captured in the retrieved OC. It should be noted that though the $\mathrm{AK}$ and these derived quantities are mainly determined by the inherent physics (i.e., $\mathbf{K}$ ), they do depend on the measurement errors, atmospheric variability, and the correlation length.

Retrieval error is another important quantity characterizing the quality of the retrievals. It consists of random and systematic errors from measurements and forward model simulations, and smoothing errors, which occur because the vertical resolution of the retrieved profile is coarser than the thickness of the layer in which the profile is reported (It should be noted that though the use of coarser layers in the state vector would reduce the smoothing errors, it increases the forward model errors. Our choice of $\sim 2.5 \mathrm{~km}$ thick layer is a compromise between the two). The random-noise error covariance matrix $\mathbf{S}_{n}$ and smoothing error covariance matrix $\mathbf{S}_{s}$ can be directly estimated from the retrievals (Rodgers, 2000):

$\mathbf{S}_{n}=\mathbf{G S}_{y} \mathbf{G}^{\mathbf{T}}$

$\mathbf{S}_{\mathbf{s}}=(\mathbf{A}-\mathbf{I}) \mathbf{S}_{a}(\mathbf{A}-\mathbf{I})^{\mathbf{T}}$

The sum of $\mathbf{S}_{n}$ and $\mathbf{S}_{s}$ is $\hat{\mathbf{S}}$ as seen in Eq. (3). The square root of diagonal elements of the $\mathbf{S}_{n}, \mathbf{S}_{s}$, and $\hat{\mathbf{S}}$ are the randomnoise errors (i.e., precisions), smoothing errors, and solution errors, respectively. The solution errors are the root 
sum square of the random-noise and the smoothing errors. Strictly speaking, the full covariance matrix of a real ensemble of states should be used to estimate $\mathbf{S}_{s}$ (Rodgers, 2000). Due to the unavailability of the full covariance matrix, we use $\mathbf{S}_{a}$, only the diagonal components of which are derived from an ensemble of states. Comparisons with ozonesonde and MLS data show that the derived smoothing errors by assuming ozonesonde/MLS as truth are generally consistent with our approximate estimates of smoothing errors using Eq. (5).

Corresponding errors in OC, SOC, and TOC can be easily calculated from the matrices by adding up errors at individual layers and removing correlated errors among different layers, so those integrated errors are usually smaller than the sum of errors at individual layers. Errors contributed from each layer to the overall OC, SOC, and TOC smoothing errors, i.e., the Column Error Contribution Function $(\mathrm{CECF}) E_{c}$, can be derived similar to Eq. (5) as:

$\boldsymbol{E}_{c}=\left(\boldsymbol{A}_{c}-\boldsymbol{I}_{c}\right) \boldsymbol{X}_{a e}$

where $\boldsymbol{X}_{a e}$ is the a priori error, $\boldsymbol{I}_{c}$ refers to the idealized $\mathrm{CAK}$. For $\mathrm{OC}$, the values of $\boldsymbol{I}_{c}$ are 1 at each layer; for $\mathrm{SOC} / \mathrm{TOC}$, the values are 1 in the stratosphere/troposphere, but 0 in the troposphere/stratosphere.

Generally, the solution errors are dominated by the smoothing errors. With regard to errors due to forward model and forward model parameter assumptions, we have found that these errors are generally similar to values in our GOME retrievals and are generally much smaller compared to the smoothing errors (Liu et al., 2005). The main sources of forward model forward parameter errors are systematic errors in temperature and cloud-top pressure; a systematic $3 \mathrm{~K}$ temperature error at all layers leads to about $10 \%$ errors for individual tropospheric layers, and an 100-hPa error in cloudtop pressure causes 6-7\% errors in the troposphere (Liu et al., 2005). The errors due to our improved on-line polarization correction (compared to vector calculations) are generally within $1 \%$ at each layer. The errors due to exclusion of the undersampling correction are less than $0.5 \%$ at each layer. Systematic measurement errors are the most difficult to evaluate; this is largely due to lack of full understanding of the OMI instrument calibration. We will determine systematic measurement errors remaining after soft calibration, by means of intercomparison with other correlative measurements.

\subsection{Retrievals to show retrieval characterization}

Figure $2 \mathrm{a}$ shows one orbit of retrieved ozone profiles on 11 July 2006. This orbit overpasses the Eastern Pacific Ocean, goes through Alaska and extends to the Arctic sea. Figure $2 \mathrm{~b}$ shows the fitted effective cloud fraction and zero-order surface albedo in UV-2, and the used effective cloud-top pressure corresponding to the retrievals. Some low/middle level clouds (with effective cloud fraction $>0.5$ ) are located

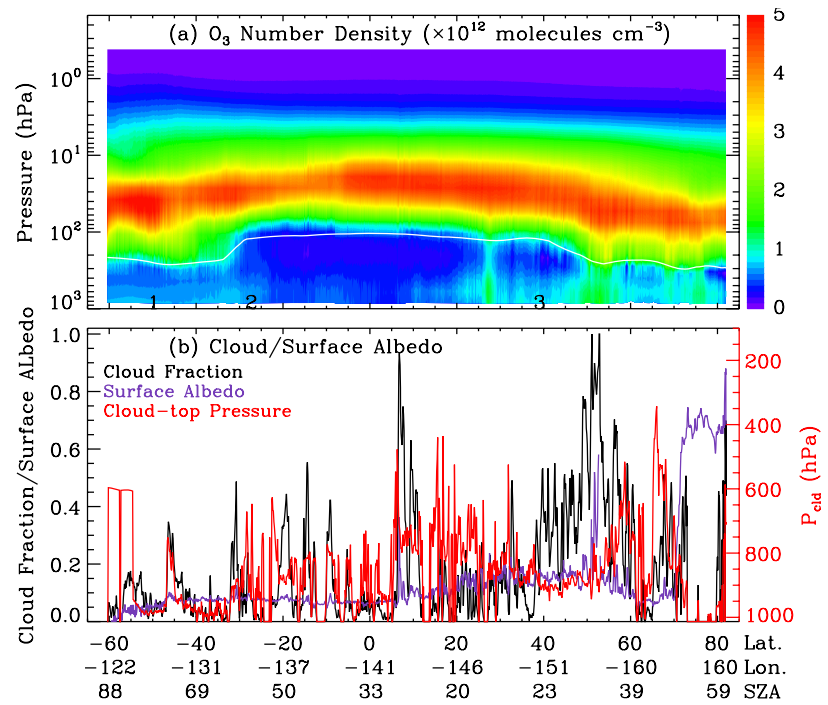

Fig. 2. An orbit of retrievals at across-track position 16 (in the UV-1 channel) on 11 July 2006 as a function of latitude, longitude, and solar zenith angle. (a) Ozone profiles in number density, and (b) the effective cloud fraction (black), fitted surface albedo (purple) for the UV-2 channel, and effective cloud-top pressure (red) used in the retrievals. The white line in (a) indicates the NCEP thermal tropopause.

around $10^{\circ} \mathrm{N}$ and $50^{\circ} \mathrm{N}$. Surface albedo in the UV is normally $5-8 \%$ over the ocean and $2-4 \%$ over land (Herman and Celarier, 1997); the fitted albedo shows elevated values at $10^{\circ} \mathrm{N}-40^{\circ} \mathrm{N}$ due to sun glint, at $70^{\circ} \mathrm{N}-85^{\circ} \mathrm{N}$ due to sea ice in the Arctic sea, and sometimes over cloudy areas, probably due to inadequate cloud modeling. Ozone number densities are highest in the pressure range $20-75 \mathrm{hPa}(20$ $27 \mathrm{~km}$ ) depending on the latitude, and closely follow the tropopause (white line). Low ozone in the tropical troposphere is transported to the middle and upper troposphere at Northern middle-latitudes (e.g., $30^{\circ} \mathrm{N}-45^{\circ} \mathrm{N}$ ) with the ridge of subtropical upper tropospheric fronts (Hudson et al., 2003). High tropospheric ozone at $28^{\circ} \mathrm{N}$ and $50^{\circ} \mathrm{N}$ is likely caused by the transport of stratospheric ozone in a folding event (mainly located at $50^{\circ} \mathrm{N}$ but with one of its tongues extending to $28^{\circ} \mathrm{N}$; this can be seen clearly in the OC map, not shown here).

Figures 3 and 4 show the retrieval characterization corresponding to the retrievals in Fig. 2, including DFS, randomnoise errors, smoothing, and solution errors at each layer (the top layer from $0.35 \mathrm{hPa}$ to the top of the atmosphere is not shown due to its broad extent) as well as in OC, SOC, and TOC. Profile AKs, CAKs and CECFs of OC, SOC, and TOC, for the three clear-sky retrievals indicated as 1, 2, 3 in Figs. $2 \mathrm{a}$ and $3 \mathrm{a}$ are shown in Figs. 5-7. Note that Figs. 4-6 also show results without retrieval dependencies (to be discussed in Sect. 4). Table 2 summarizes the average vertical resolution in terms of full width at half maximum and 
Table 2. Average vertical resolution in terms of Full Width at Half Maximum (FWHM) and relative solution/a priori errors at different altitudes for three solar zenith angles bins (all-sky conditions) for the orbit of retrievals in Fig. 2. The solution errors are defined relative to the a priori profiles.

\begin{tabular}{lcccccc}
\hline $\begin{array}{l}\text { Altitude }(\mathrm{km}) / \\
\sim \text { Pressure }(\mathrm{hPa})\end{array}$ & $<30^{\circ}$ & $30^{\circ}-60^{\circ}$ & $60^{\circ}-80^{\circ}$ & $<30^{\circ}$ & $30^{\circ}-60^{\circ}$ & $60^{\circ}-80^{\circ}$ \\
\hline $52.5 / 0.6$ & 11.8 & 12.8 & 12.1 & $4.6 / 7.6$ & $5.8 / 9.6$ & $9.5 / 16.7$ \\
$47.5 / 1.2$ & 17.5 & 14.5 & 11.3 & $3.4 / 7.2$ & $3.8 / 8.7$ & $5.0 / 14.5$ \\
$42.5 / 2.3$ & 9.6 & 9.5 & 8.9 & $1.9 / 6.6$ & $2.0 / 7.0$ & $2.7 / 10.4$ \\
$37.5 / 4.5$ & 7.7 & 7.6 & 7.5 & $1.2 / 5.2$ & $1.4 / 5.5$ & $1.7 / 6.8$ \\
$32.5 / 9.0$ & 7.2 & 7.1 & 7.3 & $1.1 / 4.6$ & $1.6 / 7.1$ & $2.1 / 9.7$ \\
$27.5 / 19.0$ & 7.6 & 7.8 & 7.6 & $1.3 / 3.7$ & $2.0 / 7.4$ & $2.6 / 10.0$ \\
$22.5 / 40.2$ & 10.7 & 14.3 & 8.3 & $2.5 / 5.6$ & $3.4 / 10.0$ & $3.4 / 9.8$ \\
$17.5 / 88.0$ & 11.6 & 10.7 & 10.9 & $9.6 / 23.1$ & $8.3 / 18.7$ & $8.1 / 20.4$ \\
$12.5 / 192.3$ & 14.3 & 14.1 & 13.9 & $24.7 / 41.7$ & $15.6 / 30.2$ & $13.8 / 33.0$ \\
$7.5 / 397.0$ & 12.5 & 11.4 & 13.7 & $15.2 / 31.0$ & $14.5 / 30.9$ & $23.3 / 38.8$ \\
$2.5 / 758.0$ & 10.0 & 9.6 & 12.2 & $19.7 / 33.7$ & $17.2 / 26.1$ & $16.7 / 18.8$ \\
\hline
\end{tabular}

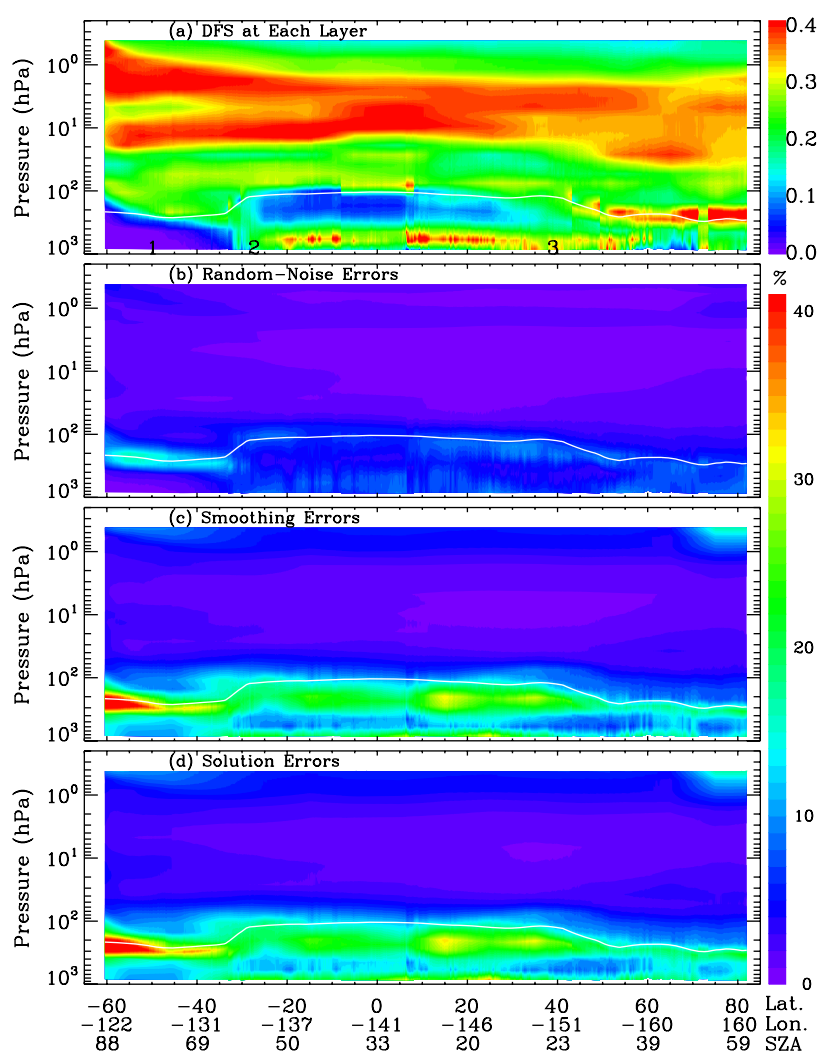

Fig. 3. (a) Degrees of freedom for signal at each layer, (b) $1 \sigma$ random-noise errors, (c) $1 \sigma$ smoothing errors, and (d) $1 \sigma$ solution errors (i.e., root sum square of (b) and (c)) for the same orbit of retrievals as in Fig. 2.

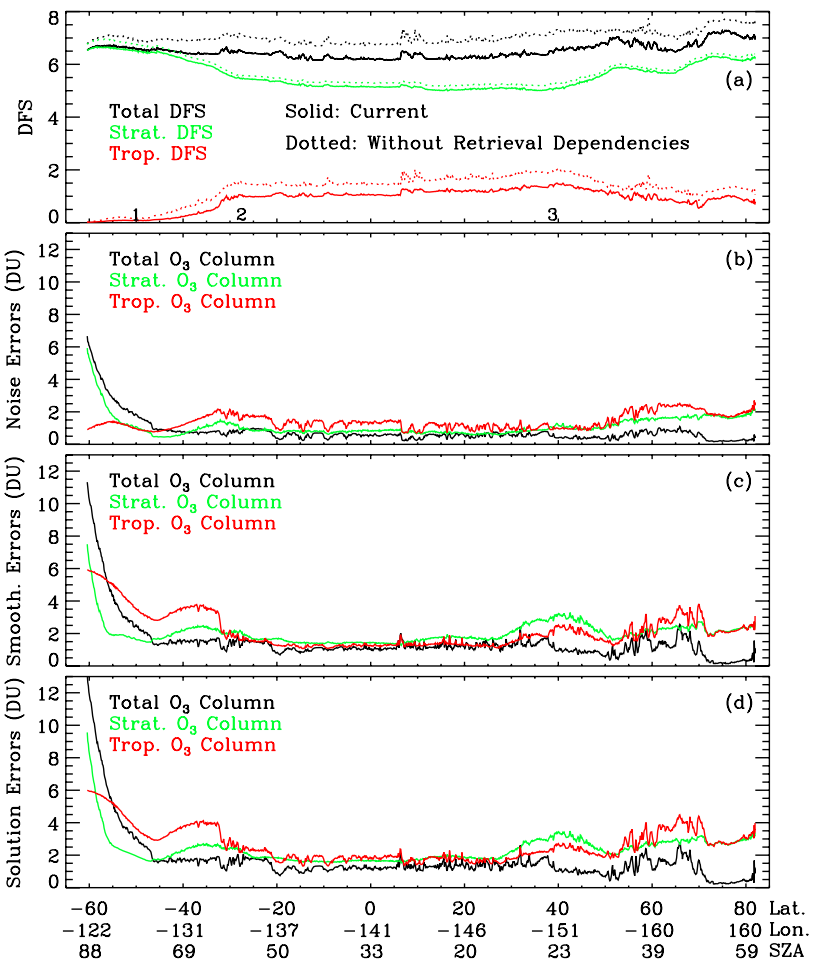

Fig. 4. (a) Total, stratospheric, and tropospheric degrees of freedom for signal, (b) $1 \sigma$ random-noise errors in total, stratospheric, and tropospheric ozone columns, (c) same as (b) but for $1 \sigma$ smoothing errors, and (d) same as (b) but for $1 \sigma$ solution errors (i.e., root sum square of (b) and (c)), for the same orbit of retrievals as in Fig. 2. The dotted lines in (a) are for retrievals under ideal conditions (i.e., without retrieval dependencies on other parameters). 
solution errors vs. altitude for three SZA bins $\left(\mathrm{SZA}<30^{\circ}\right.$, $30^{\circ}<\mathrm{SZA}<60^{\circ}, 60^{\circ}<\mathrm{SZA}<80^{\circ}$ ), and Table 3 summarizes the average total, stratospheric and tropospheric DFS and solution errors in OC, SOC, and TOC. The overestimate of measurement errors in OMI level $1 \mathrm{~b}$ data, which was mentioned in Sect. 2.5, has been corrected in all these figures and tables; this correction increases mean total DFS by 0.75 $(0-1.2)$ and tropospheric DFS by $0.15(0-0.3)$ and slightly reduces retrieval errors.

Averaging kernels for some layers show large oscillations (values can be outside the range $[-1,1]$ ) at high altitudes, suggesting that retrieved ozone values in these layers are very sensitive to ozone changes at high altitude. However, actual retrievals are barely affected by these large values, because overall changes in ozone from a priori values at high altitudes are very small $(<0.05 \mathrm{DU})$. To better represent the actual retrieval sensitivity visually and dampen these large oscillations, the AKs in Fig. 5 have been normalized by the a priori errors. Since averaging kernels operate on the differences between true and a priori profiles, which are statistically represented by a priori errors, this normalization is equivalent to plotting the averaging kernels for retrieving a modified state vector that has a priori error of 1 at each layer.

\subsection{Retrieval sensitivity}

Figure 3a shows the DFS at each layer. In the stratosphere, the DFS is generally highest over the pressure range 1$30 \mathrm{hPa}(25-45 \mathrm{~km})$. There is a second maximum around the tropopause for about $50^{\circ} \mathrm{N}-80^{\circ} \mathrm{N}$. There is little tropospheric information for $60^{\circ} \mathrm{S}-35^{\circ} \mathrm{S}$ due to limited photon penetration into the troposphere as a result of high SZA and low surface albedo conditions. Under other clear-sky conditions, the DFS generally peaks in the $500-700 \mathrm{hPa}$ layer. Sometimes, DFS can peak in the first layer when there are low-level clouds or snow/ice surfaces. The relatively weak vertical information in the tropical upper troposphere is because SZA is low, ozone column in the stratosphere is small, and multiple scattering generally peaks at lower altitudes. However, the RE for this altitude range is almost 1, since ozone in this altitude range can be well captured in the ozone profile, but will be smoothed to a broad altitude range.

The total DFS value is $\sim 6-7.3$, with values of $5-6.7$ in the stratosphere and 0-1.5 in the troposphere (Fig. 4a, Table 3). Stratospheric DFS usually increases at high SZA due to the longer photon path length that increases the vertical discrimination of ozone at higher altitudes. Tropospheric DFS decreases quickly at SZA larger than $60^{\circ}$ for the same reason (reduced photon penetration to lower altitudes). At $35^{\circ} \mathrm{S}-$ $45^{\circ} \mathrm{N}$, tropospheric DFS is not adversely affected by the existence of low-level clouds and is sometimes enhanced, because clouds enhance ozone sensitivity above them, as well as shielding information below them.

From the examples shown in Figs. 5a-c, we can see that AKs are well defined and ozone profiles are well resolved

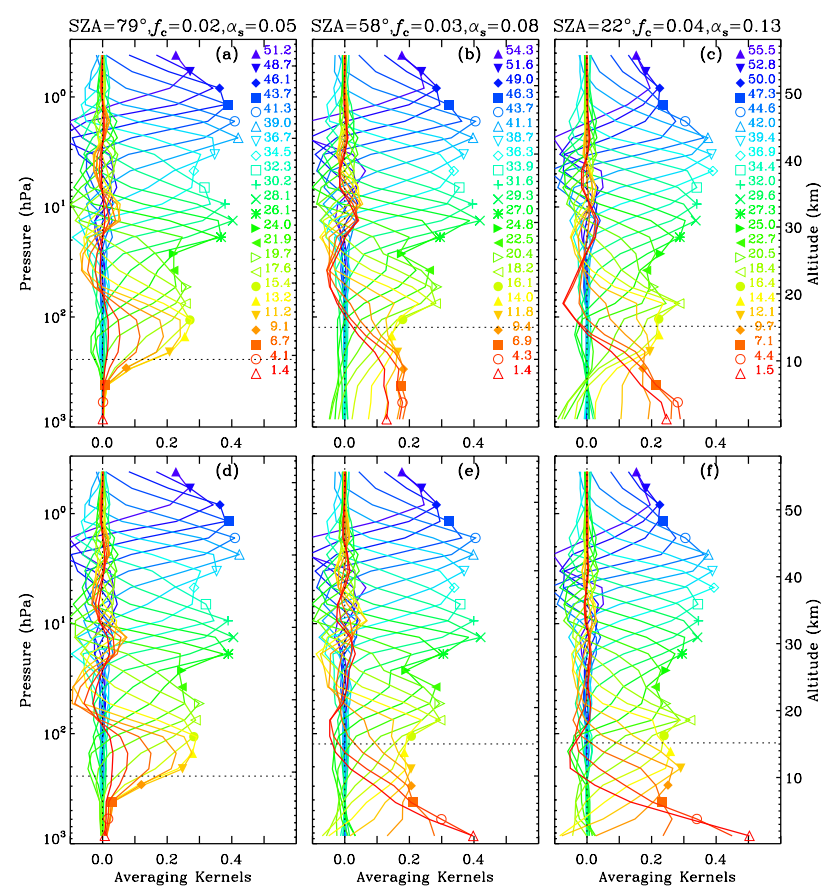

Fig. 5. (a-c) are three examples of nearly clear-sky retrieval averaging kernels for pixels (1-3) indicated on Figs. 2a and 3a. (d-e) are the same as $(\mathrm{a}-\mathrm{c})$ but under ideal conditions (i.e., without retrieval dependencies on other parameters). These AKs have been normalized by the actual ozone variability (i.e., a priori error). The symbols indicate the altitude of the averaging kernels. The dotted black horizontal lines indicate the tropopause. The caption on top of each of panel shows solar zenith angle, cloud fraction, and surface albedo.

in the stratosphere. The average vertical resolution is about $7-11 \mathrm{~km}$ over the pressure range $1.5-100 \mathrm{hPa}$ or $15-45 \mathrm{~km}$ (Table 2). In the troposphere, some AKs are not well defined due to inadequate sensitivity (Fig. 5a) and most AK peak altitudes are not coincident with their nominal altitude values. Where the AKs are defined (peak altitudes are within $6 \mathrm{~km}$ of nominal altitudes), the average vertical resolution is 10 $14 \mathrm{~km}$ (Table 2).

The REs or OC AKs (blue lines in Fig. 6) are generally $\sim 1$ above the first layer except for $\sim 60^{\circ} \mathrm{S}-40^{\circ} \mathrm{S}$ due to little information (e.g., Fig. 6a) or regions with high-level clouds; the oscillations around 1 arise from the assumed a priori covariance matrix. The RE in the first layer (centered at $\sim 850 \mathrm{hPa}$ ) is generally $\sim 0.4-0.7$ for most of the tropical and mid-latitude summer clear-sky conditions (e.g., Figs. 6b-c), and the corresponding effective photon penetration depth is $800-900 \mathrm{hPa}$ for these conditions. When there are low-level clouds or snow/ice surfaces (e.g., $70^{\circ} \mathrm{N}-80^{\circ} \mathrm{N}$ ), the RE in the first layer can be greater than 0.9.

When there is little tropospheric information, the TOC CAK centers around zero and SOC CAK is almost the same as the OC CAK (Fig. 6a). Under other conditions, the SOC 
Table 3. Average total, stratospheric, and tropospheric Degree of Freedom for Signal (DFS) and solution/a priori errors in total, stratospheric, and tropospheric ozone columns for three solar zenith angles bins (all-sky conditions) for the orbit of retrievals in Fig. 2.

\begin{tabular}{lcccccc}
\hline & \multicolumn{3}{c}{ DFS } & \multicolumn{3}{c}{ Solution/A Priori Errors (DU) } \\
& $<30^{\circ}$ & $30^{\circ}-60^{\circ}$ & $60^{\circ}-80^{\circ}$ & $<30^{\circ}$ & $30^{\circ}-60^{\circ}$ & $60^{\circ}-80^{\circ}$ \\
\hline Total & 6.4 & 6.6 & 6.6 & $1.3 / 16.6$ & $1.2 / 21.7$ & $2.0 / 30.0$ \\
Stratospheric & 5.1 & 5.6 & 6.2 & $2.3 / 11.6$ & $2.2 / 18.3$ & $2.9 / 26.9$ \\
Tropospheric & 1.3 & 1.0 & 0.4 & $1.9 / 9.8$ & $2.5 / 8.1$ & $4.4 / 7.1$ \\
\hline
\end{tabular}

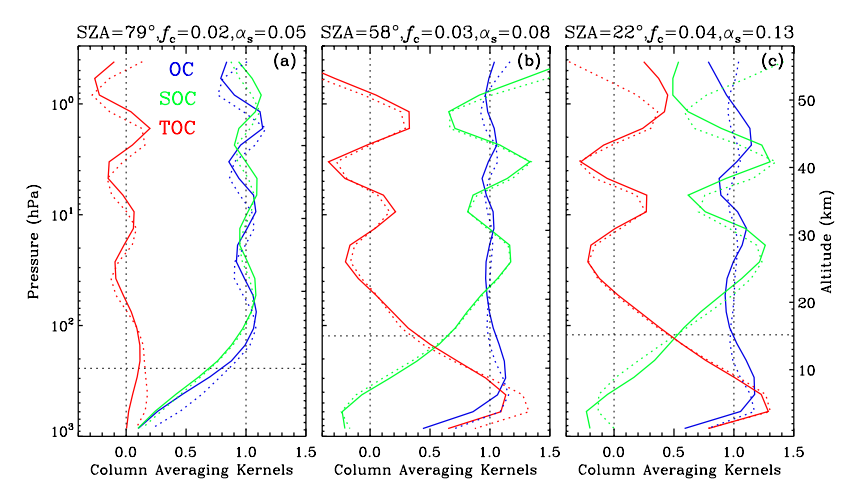

Fig. 6. Column averaging kernels in total, stratospheric and tropospheric ozone columns (OC, SOC, and TOC) corresponding to the three examples in Fig. 5. The solid lines are for current retrievals and the dotted lines are for retrieval without retrieval dependencies.

(green lines) and TOC (red lines) CAKs in Figs. 6b-c peak in the stratosphere and troposphere, respectively, as expected. But both show significant sensitivity from the other part of the atmosphere, especially in the lower stratosphere and upper troposphere, and both show larger stratospheric oscillations than the OC CAK. This seems to indicate large smoothing errors in the retrieved SOC and TOC and the difficulty in separating TOC from SOC. However, it should be noted that the smoothing process operates on the difference in layer ozone column amount (in DU) between actual and a priori ozone profiles (as indicated by the a priori error in Fig. 7) instead of the actual profile itself. Figure 7 shows that the errors contributed from each layer arising from imperfect CAKs are very small in the middle and upper stratosphere $(<0.5 \mathrm{DU})$ and are generally within $2 \mathrm{DU}$ in the lower stratosphere and troposphere. If we assume that errors at individual layers are random and uncorrelated, then the errors in OC, SOC, and TOC are the root sum squares of the errors at individual layers. Those integrated errors are very small, 1.4 DU, 2.3 DU, 2.3 DU in OC, SOC, and TOC, respectively for Fig. $7 \mathrm{~b}$, close to the estimates of smoothing errors (1.6, 2.1 , and $1.8 \mathrm{DU}$, respectively).

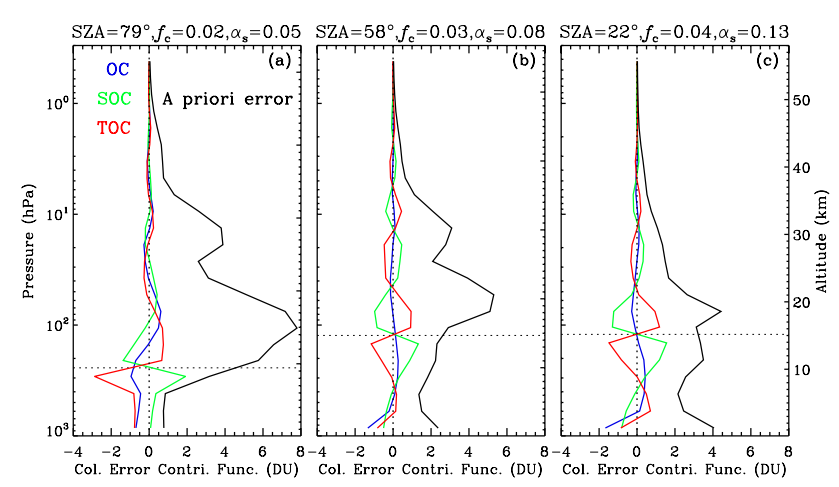

Fig. 7. Column error contribution function $(1 \sigma)$ for total, stratospheric and tropospheric ozone columns (OC, SOC, and TOC) corresponding to the three examples in Fig. 5. Also plotted is the a priori error (black) at each layer.

\subsection{Retrieval errors}

Figures $3 b-d$ show the random-noise, smoothing, and solution errors at each layer. The random-noise errors are typically $0.5-2 \%$ in the major part of the stratosphere $(0.4-$ $76 \mathrm{hPa}$ ). They increase to as much as $10 \%$ in the lower stratosphere and troposphere (and occasionally to $\sim 16 \%$, e.g., in the upper troposphere and lower stratosphere for $60^{\circ} \mathrm{S}-50^{\circ} \mathrm{S}$ due to weak ozone information). The smoothing errors are generally much larger than random-noise errors, dominating the solution errors, especially over altitude regions with weak ozone information. The solution errors (also shown in Table 2) are typically within 1-6\% in the middle and upper stratosphere $(1-50 \mathrm{hPa})$, increasing to $10 \%$ (occasionally to $17 \%$ ) for pressure $<1 \mathrm{hPa}$. In the lower stratosphere and troposphere, they are generally within $6-35 \%$ but sometimes as high as $50 \%$ for $60^{\circ} \mathrm{S}-50^{\circ} \mathrm{S}$ due to low ozone information and relatively large climatological variability; the average errors are $8-25 \%$ as shown in Table 2.

Figures $4 \mathrm{~b}-\mathrm{d}$ show corresponding random-noise, smoothing, and solution errors in OC, SOC, and TOC. Although these errors vary with many factors including SZA, OC, the vertical distribution of ozone, cloud, and surface albedo, the overall errors are quite small except for high $\mathrm{SZA}>80^{\circ}$, where the errors increase quickly with the increase of high 
solar zenith angles. At $\mathrm{SZA}<80^{\circ}$, the random-noise errors are within $2 \mathrm{DU}$ for OC and SOC and within $3 \mathrm{DU}$ for TOC; the solution errors are within 3.5 DU for OC and SOC and within 5 DU for TOC. As shown in Table 3, the average solution errors are 1-2 DU in OC, 2-3 DU in SOC, and 2-5 DU in TOC for different SZA ranges. Note that those very small errors ( $<0.5 \mathrm{DU})$ in $\mathrm{OC}$ at $70^{\circ} \mathrm{N}-80^{\circ} \mathrm{N}$ are due to highly reflecting snow/ice surfaces.

\section{Retrieval dependencies and further algorithm improvements}

The previous section shows that current OMI retrievals effectively exhibit full sensitivity to ozone down to the 800$900 \mathrm{hPa}$ range or the upper part of the boundary layer. It should be noted that sensitivity to boundary layer ozone has not been fully exploited from OMI measurements due to retrieval dependencies with other ancillary parameters, especially the wavelength-dependent surface albedo parameters. Because the limited ozone information for the boundary layer partly originates from the broad variation of ozone absorption with wavelength, it correlates with signatures from aerosols and surface albedo. Thus, fitted wavelengthdependent surface albedo parameters are cross-correlated with ozone parameters, reducing the sensitivity to ozone.

The dotted lines in Fig. 4a show the DFS values without retrieval dependencies on other non-ozone parameters. These values would increase by $0.4-0.7$ at $40^{\circ} \mathrm{S}-80^{\circ} \mathrm{N}$ and the tropospheric DFS would increase by $0.2-0.6$, mainly from the first layer (0.1-0.35 from the first layer). For most retrievals at $30^{\circ} \mathrm{S}-80^{\circ} \mathrm{N}$, DFS values in the first layer would be comparable or larger than those in the second layer. AKs in the troposphere would be better defined and the vertical resolution would be improved.

Figures $5 \mathrm{~d}-\mathrm{f}$ show the same AKs as those in Fig. 5a-c except without retrieval dependencies. We can see significant improvement in the first layer and in the troposphere overall for the second and third examples. The vertical resolution in the troposphere would be improved from 10-14 km to 5-12 km; the RE (dotted lines in Fig. 6) would increase to $0.7-0.8$ for the first layer, and the effective photon penetration depth would be $920-950 \mathrm{hPa}$, almost down to the surface. In addition, the oscillations in OC, SOC and TOC AKs would be slightly reduced, and retrieval errors would also be reduced.

The effects of retrieval dependencies suggest that in order to further improve retrievals, especially those in the boundary layer, we need (1) to obtain better instrument calibration, (2) to use other auxiliary information (e.g., temperature profiles, aerosols, cloud, surface pressure) as accurately as possible, and (3) improve the accuracy of the forward model parameters. Further improvements of the retrieval algorithm for OMI could include the addition of longer wavelengths to derive aerosol information, the simulation of radiances at a higher spectral resolution before convolution with instrumental slit functions, the modeling of the bi-directional reflectance distribution functions for the surface (including sun-glint), and the treatment of clouds as scattering layers as opposed to Lambertian reflecting boundaries.

Even if we can significantly reduce the retrieval dependencies and improve the sensitivity to boundary layer ozone, the lack of adequate vertical information cannot sufficiently separate boundary layer ozone from free tropospheric ozone using UV radiance measurements alone. Combining UV radiance measurements with polarization measurements in the UV (Hasekamp and Landgraf, 2002), and radiance measurements in the Chappuis bands (Chance et al., 1997) and thermal IR (Worden et al., 2007), are potential avenues for improving ozone retrievals in the boundary layer or at the surface. The keys to these combined retrievals are to calibrate different measurements in a consistent manner and to establish spectroscopic databases that are relatively consistent among different spectral regions.

\section{Comparison of retrieval characteristics between OMI, GOME, and SBUV}

Because ozone profiles have been previously measured from SBUV-like (i.e. from BUV) and GOME measurements since 1970 and 1995, respectively (Bhartia et al., 1996; Liu et al., 2005), it is important to understand the differences in retrieval characteristics (e.g., vertical resolution and retrieval errors) among these measurements. To minimize the effects of factors such as a priori covariance matrix, viewing geometry, ozone fields, and retrieval parameters on the comparison, we modify the OMI level $1 \mathrm{~b}$ data to SBUV and GOMElike measurements and perform retrievals from the same orbit in Fig. 2. To represent SBUV retrievals, we convolve OMI measurements to the SBUV spectral resolution (1.13$\mathrm{nm}$ FWHM) and interpolate convolved data to SBUV wavelengths (except for $255.5 \mathrm{~nm}$, not measured in OMI). A measurement error of $1 \%$ is assumed at each wavelength following the SBUV operational algorithm (Bhartia et al., 1996); the use of $1 \%$ error is to account for the scene change during the course of a sequential scan of all the wavelengths. A major difference between our OMI and GOME algorithms is the use of a different spectral range (290-307 nm, 325-340 nm) in the latter (Liu et al., 2005). To investigate how this affects retrievals, we use OMI data (same spectral resolution and signal to noise ratio) with this modified spectral range. We use the same a priori covariance matrix and retrieval parameters for all these three retrievals. Tables 4 and 5 show similar comparisons as Tables 2 and 3 but for these three retrievals at SZA between $30^{\circ}-60^{\circ}$.

For retrievals with the modified spectral range, the total DFS is smaller by 1.7 mainly in the stratosphere because of not using measurements below $290 \mathrm{~nm}$. Corresponding, vertical resolution is significantly coarser than OMI's resolution 
Table 4. Similar to Table 2, but for comparison of OMI, GOME, and SBUV retrievals at solar zenith angles $30^{\circ}-60^{\circ}$.

\begin{tabular}{|c|c|c|c|c|c|c|}
\hline \multirow{2}{*}{$\begin{array}{l}\text { Altitude }(\mathrm{km}) / \\
\sim \text { Pressure }(\mathrm{hPa})\end{array}$} & \multicolumn{3}{|c|}{ FWHM (km) } & \multicolumn{3}{|c|}{ Solution Errors (\%) } \\
\hline & OMI & GOME & SBUV & OMI & GOME & SBUV \\
\hline $52.5 / 0.6$ & 12.8 & 21.5 & 14.1 & 5.8 & 7.7 & 6.6 \\
\hline $47.5 / 1.2$ & 14.5 & 20.1 & 15.7 & 3.8 & 5.2 & 4.9 \\
\hline $42.5 / 2.3$ & 9.5 & 16.2 & 13.8 & 2.0 & 3.4 & 3.6 \\
\hline $37.5 / 4.5$ & 7.6 & 13.5 & 10.7 & 1.4 & 2.3 & 2.9 \\
\hline $32.5 / 9.0$ & 7.1 & 9.4 & 9.9 & 1.6 & 2.2 & 3.8 \\
\hline $27.5 / 19.0$ & 7.8 & 8.9 & 11.4 & 2.0 & 2.4 & 4.1 \\
\hline $22.5 / 40.2$ & 14.3 & 13.3 & 22.6 & 3.4 & 4.0 & 6.0 \\
\hline $17.5 / 88.0$ & 10.7 & 12.6 & 20.4 & 8.3 & 9.7 & 13.2 \\
\hline $12.5 / 192.3$ & 14.1 & 16.7 & 25.0 & 15.6 & 16.9 & 21.5 \\
\hline 7.5/397.0 & 11.4 & 13.4 & 24.6 & 14.5 & 16.4 & 24.8 \\
\hline $2.5 / 758.0$ & 9.6 & 10.8 & 19.2 & 17.2 & 19.1 & 24.9 \\
\hline
\end{tabular}

Table 5. Similar to Table 3, but for comparison of OMI, GOME, and SBUV retrievals at solar zenith angles $30^{\circ}-60^{\circ}$.

\begin{tabular}{lcccccc}
\hline & \multicolumn{3}{c}{ DFS } & \multicolumn{3}{c}{ Solution Errors (DU) } \\
& OMI & GOME & SBUV & OMI & GOME & SBUV \\
\hline Total & 6.6 & 4.8 & 3.7 & 1.2 & 1.5 & 4.1 \\
Stratospheric & 5.6 & 3.9 & 3.5 & 2.2 & 2.7 & 4.6 \\
Tropospheric & 1.0 & 0.9 & 0.3 & 2.5 & 3.3 & 6.3 \\
\hline
\end{tabular}

in the upper stratosphere. The tropospheric DFS is only slightly smaller. The solution errors are larger by $0.5-2 \%$ (from 1-6\% to 2-8\%) at each layer and are slightly larger for OC, SOC, and SOC.

For SBUV retrievals, most of the tropospheric DFS $(<0.5)$ is lost and the stratospheric DFS is reduced by 2 due to the use of only 11 discrete wavelengths and a large measurement error. The vertical resolution is $10-14 \mathrm{~km}$ over the pressure range $1.5-26 \mathrm{hPa}(25-45 \mathrm{~km})$. The vertical resolution in the lower stratosphere and troposphere is $20-25 \mathrm{~km}$, confirming the fact that ozone column below $25 \mathrm{~km}$ can still be well derived from the SBUV measurements (Bhartia et al., 1996). The solution errors increase by 1-3\% (from 1-6\% to 3-7\%) in the stratosphere and by $5-10 \%$ in the troposphere; errors in $\mathrm{OC}, \mathrm{SOC}$, and $\mathrm{OC}$ are more than doubled compared to OMI retrievals. Note that the vertical resolution of 10-14 km above ozone density peak is significantly poorer than that estimated from the operational algorithm $(6-8 \mathrm{~km})$. This is primarily due to the use of a different a priori covariance matrix. A priori error of $50 \%$ is used at each layer to better capture ozone trend from the operational SBUV retrievals, which increases the stratospheric DFS by 1.5 .

\section{Examples of retrievals}

Figure 8 shows global maps of OC, SOC, TOC, and effective cloud fraction on 26 August 2006. Figure 9 shows longitudinal cross sections of ozone below $100 \mathrm{hPa}$ at $10.5^{\circ} \mathrm{S}$ and $35.5^{\circ} \mathrm{N}$, interpolated to fine vertical grids and converted to volume mixing ratio. Large values of OC and SOC at middle latitudes generally correspond to regions of tropopause folding, i.e., with large tropopause pressure (black contours on OC and SOC maps). TOC in the tropics shows typical wave-1 pattern, with low TOC over regions of strong convection (e.g., the Pacific Ocean) and high ozone over the South Atlantic due to complex coupling between biomass burning, lightning $\mathrm{NO}_{\mathrm{x}}$, and dynamic transport processes (Thompson et al., 2000; Martin et al., 2002; Edwards et al., 2003; Sauvage et al., 2006, 2007). The longitudinal cross section of ozone profiles at $10.5^{\circ} \mathrm{S}$ in Fig. 9a shows enhanced ozone of $60-90 \mathrm{ppbv}$ in the middle troposphere of South Atlantic, also moderately high ozone of $60 \mathrm{ppbv}$ around Indonesia due to the early stage of the 2006 El Niño event (Logan et al., 2008), as well as low ozone of 20-40 ppbv throughout the troposphere of the Pacific Ocean.

Zonal bands of high TOC are found at middle latitudes $\left(25^{\circ} \mathrm{N}-55^{\circ} \mathrm{N}, 20^{\circ} \mathrm{S}-40^{\circ} \mathrm{S}\right)$ in both hemispheres. Particularly in the northern middle latitudes, enhanced TOC regions are located over central and eastern US and its outflow area, the west coast of Europe, the Mediterranean, the middle 

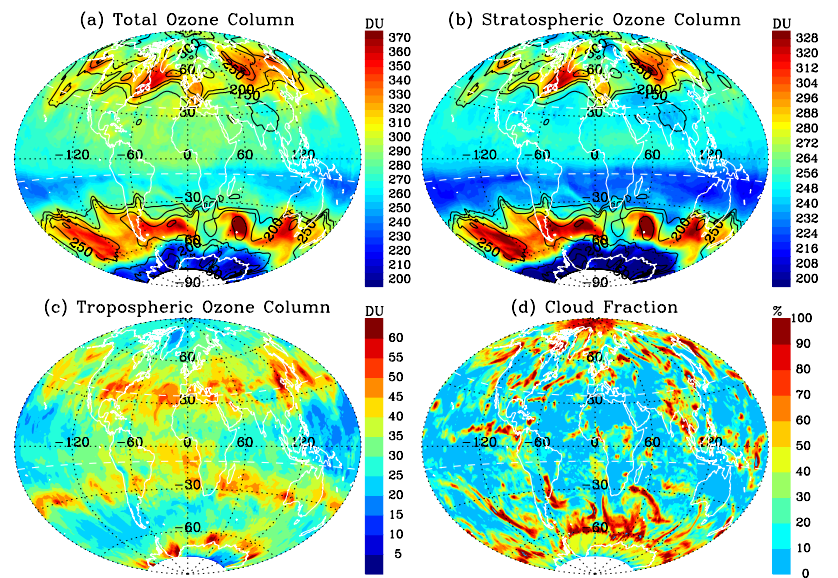

(d) Cloud Fraction

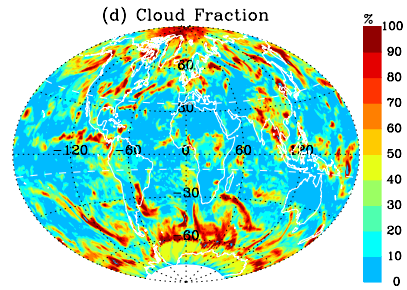

Fig. 8. Maps of total ozone column (a), stratospheric ozone column (b), tropospheric ozone column (c), and cloud fraction (d) on 26 August 2006. The data are mapped on $1^{\circ}$ longitude $\times 1^{\circ}$ latitude grid cells. Some systematic cross-track position dependent biases have been removed before gridding by assuming these data do not vary with cross-track position within a month. The black contours on (a) and (b) indicate the NCEP tropopause pressure used (The contour levels are 100,150,200,250,300,350 hPa) and the two white dashed lines indicate the latitudes where zonal cross sections of tropospheric ozone profiles are shown in Fig. 9.

East, East Asia and its outflow regions. These high ozone features are not caused by retrieval artifacts associated with clouds since they do not always correspond to high cloudiness (Fig. 8d). Some of these ozone enhancements will reflect the transport of industrial pollution from the continents; this have been shown from many modeling studies (Parrish et al., 1993; Lelieveld et al., 2002; Liu et al., 2003; Duncan and Bey, 2004; Auvray and Bey, 2005; Li et al., 2005; Cooper et al., 2007). Some of these features could also be caused by stratospheric intrusions (Cooper et al., 2004a, 2005). For example, Fig. $9 \mathrm{~b}$ shows the transport of high ozone from the stratosphere to the middle troposphere at $150^{\circ} \mathrm{W}$, associated with a tropopause folding as seen from the NCEP tropopause. Due to limited vertical resolution and the fact that pollution plumes from continental outflows often mix with stratospheric air masses (Cooper et al., 2004a, 2005), it is difficult to identify the origins of these high ozone features from OMI retrievals alone. It is necessary to use other in-situ observations, model simulations, and meteorological fields to assist with the interpretation of OMI retrievals. It is likely that high ozone in the southern middle latitudes is due to stratospheric intrusion as well as the lifting of ozone precursors from biomass burning to the upper troposphere.

There is large spatial variability at middle latitudes, with a mixture of high ozone features with low ozone features due in part to frequent transport of tropical marine air to middle and high latitudes as can be seen from Fig. $8 \mathrm{c}$ and Fig. 9b (e.g., $180^{\circ} \mathrm{W}, 140^{\circ} \mathrm{W}, 50^{\circ} \mathrm{W}, 40^{\circ} \mathrm{E}, 140^{\circ} \mathrm{E}, 160^{\circ} \mathrm{E}$ ). Fig-

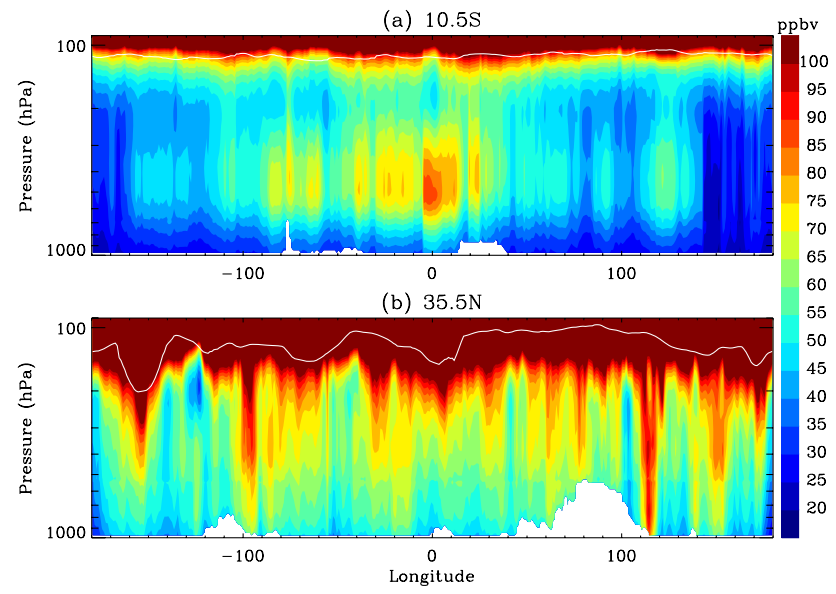

Fig. 9. Longitudinal cross sections of ozone volume mixing ratio from the surface to $100 \mathrm{hPa}$ at $10.5^{\circ} \mathrm{S}$ and $35.5^{\circ} \mathrm{N}$, corresponding to the dashed white lines in Fig. 8. The retrieved partial ozone columns are interpolated to a finer vertical grid and are converted to volume mixing ratio. The white lines indicate the NCEP tropopause.

ure $9 \mathrm{~b}$ shows low ozone values of $30-40 \mathrm{ppbv}$ in the upper troposphere at $125^{\circ} \mathrm{W}$, which is likely due to the transport of tropical marine air based on the animation of daily maps.

TOC at high latitudes is generally low partly due to lower tropopause except over Antarctica, where high TOC is because the NCEP tropopause is too high $(<150 \mathrm{hPa})$. The low TOC over the Himalayas, Greenland, Andes, and Rocky mountains is due to high terrain; when converted to mean mixing ratio, the values are similar to or slightly higher than those in surrounding areas.

The high spatial resolution and daily global coverage of OMI observations make our retrievals especially suitable for tracking the spatiotemporal evolution of ozone features caused by chemical and dynamic processes, such as the longrange transport of pollution, stratospheric folding events, and transport of low-ozone tropical marine air to higher latitudes. Figure 10 shows mean tropospheric ozone mixing ratio as well as longitudinal cross sections of ozone profiles below $100 \mathrm{hPa}$ at $31.5^{\circ} \mathrm{N}$ and $41.5^{\circ} \mathrm{N}$ over the North Pacific during an event of transpacific transport of pollution on 5-9 May 2006. This event has been well studied by Zhang et al. (2008); the Asia pollution plume is lifted by a southeastward moving front and is rapidly transported in westerly winds across the Pacific.

The progression of this transport event can be seen clearly from Atmospheric Infrared Sounder (AIRS) observations and GEOS-Chem simulations of CO (Fig. 7 of Zhang et al., 2008). OMI retrievals (Fig. 10a) show features very similar to the spatiotemporal distribution of $\mathrm{CO}$ except for some high ozone likely due to stratospheric intrusions. For example, the high-ozone stream over the west coast of the US where there is low CO is not caused by the transport of Asian pollution, but by a stratospheric folding event, the spatiotemporal 


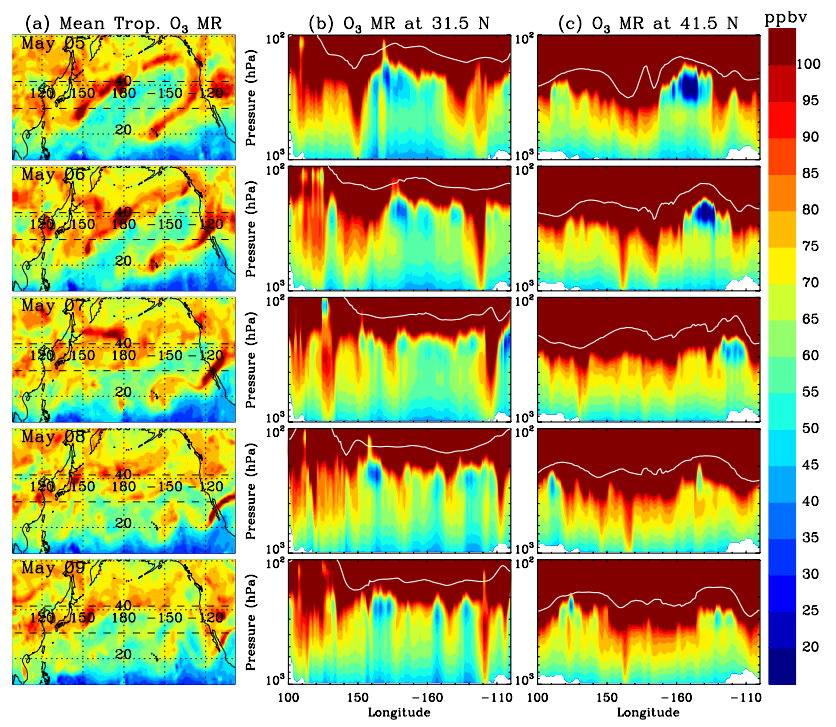

Fig. 10. An event of transpacific transport of pollution from East Asia across the North Pacific Ocean to the United States on 5-9 May 2006. (a) Mean tropospheric ozone volume mixing ratio, (b) longitudinal cross sections of ozone profiles below $100 \mathrm{hPa}$ at $31.5^{\circ} \mathrm{N}$ and (c) same as (b) but at $41.5^{\circ} \mathrm{N}$. The dashed lines on (a) indicate the latitudes of cross sections. The white lines indicate the NCEP tropopause. The data are mapped on $1^{\circ}$ longitude $\times 1^{\circ}$ latitude grid cells.

evolution of which can also be clearly seen from Figs. 10a and $b$. The cross sections also clearly indicate significant stratospheric influences, even in regions of pollution transport, as many high ozone features are well connected to high ozone above. The coexistence of stratospheric intrusion with transport of pollution is consistent with the findings of Cooper et al. (2004a, b) that stratospheric air masses often mix with pollution plumes in regions of continental outflow. In the above example, on 9 May, part of the pollution plume reached the west coast of the US. Aircraft observations near $138^{\circ} \mathrm{W}, 42^{\circ} \mathrm{N}$ show ozone of $25-45 \mathrm{ppbv}$ in the lower troposphere $(0-2.5 \mathrm{~km})$ and $60-80 \mathrm{ppbv}(3.5-10 \mathrm{~km})$ in the middle troposphere, and illustrate the decomposition of peroxyacetylinitrate (PAN) and the production of ozone (Fig. 9 of Zhang et al., 2008). OMI ozone profiles over this region show ozone values of $70 \mathrm{ppbv}$ over $2.5-10 \mathrm{~km}$, consistent with aircraft observations, but show much higher values of 55 ppbv over $0-2.5 \mathrm{~km}$ (Fig. 10c). Another distinct feature from this event is the transport of low-ozone tropical air with the southeastward moving front. Despite coarse vertical resolution, OMI retrievals clearly track horizontal, vertical, and temporal transport of these features. Sometimes low ozone is transported to the upper troposphere, above relatively higher ozone.

\section{Summary}

We have applied our ozone profile retrieval algorithm, originally developed for the Global Ozone Monitoring Experiment (GOME), to the Ozone Monitoring Instrument (OMI) data. Because OMI instrument characteristics are dissimilar, we use a different strategy to deal with radiometric calibration. The OMI retrievals also use an improved radiative transfer model. To check the radiometric calibration of OMI, we compare radiances simulated with zonal mean Microwave Limb Sounder (MLS) ozone profiles in the tropics with OMI observations. OMI UV radiances show significant across-track and wavelength dependent biases (typically -6$7 \%$ ) as well as discontinuities of $3-9 \%$ at $310 \mathrm{~nm}$ between UV-1 and UV-2 channels. A first-order correction is derived by averaging two days' radiance differences, and applied independent of space and time to OMI radiances prior to the retrievals. From corrected OMI radiances $(270-330 \mathrm{~nm})$, we retrieve partial ozone columns at 24 approximately $2.5-\mathrm{km}$ layers between the surface and $\sim 60 \mathrm{~km}$ using the optimal estimation technique. Total, stratospheric, and tropospheric ozone column (OC, SOC, TOC) are directly integrated from the retrieved profiles.

There are 6-7.3 degrees of freedom for signal in the retrievals with 5-6.7 in the stratosphere and up to 1.5 in the troposphere. In the stratosphere, ozone information generally peaks between $1-30 \mathrm{hPa}$ with vertical resolution of $7-11 \mathrm{~km}$. In the tropics and mid-latitude summer, tropospheric information generally peaks between $500-700 \mathrm{hPa}$ with vertical resolution of $10-14 \mathrm{~km}$, and the retrievals are effectively sensitive to ozone down to $\sim 800-900 \mathrm{hPa}$. The random-noise errors (i.e., precisions) are typically $0.5-2 \%$ in the middle stratosphere, 3-5\% in the upper stratosphere and increase to as much as $10 \%$ in the lower stratosphere and troposphere. The solution errors, i.e., root sum square of both randomnoise and smoothing errors, are dominated by smoothing errors; they are generally $1-6 \%$ in the middle stratosphere, up to $10 \%$ in the upper stratosphere, and 6-35\% in the troposphere. OC, SOC, and TOC can be accurately retrieved. Under solar zenith angles less than $80^{\circ}$, the precisions are generally within $2-3 \mathrm{DU}$, and the solution errors are generally less than 4-5 DU.

We present several examples of retrievals with an emphasis on tropospheric ozone, although there is much more information in the stratosphere than in the troposphere. OMI retrievals are capable of capturing tropospheric ozone signals due to convection, biomass burning, anthropogenic pollution, transport of pollution, transport of low ozone tropical air to the middle and upper troposphere of middle and high latitudes, and stratospheric intrusions. Despite coarse vertical resolution, OMI's high spatial resolution and daily global coverage make our retrievals suitable for tracking the spatiotemporal evolutions of tropospheric ozone features caused by chemical and dynamic processes. 
Due to the vertical distribution of ozone information spanning both the stratosphere and the troposphere, high retrieval precision, accurate estimates of OC, SOC and TOC, and OMI's spatial resolution and coverage, OMI ozone profiles constitute a unique and useful dataset to study the distribution of ozone in the troposphere and the stratosphere. This dataset complements ozone measurements from the other instruments on the Aura satellite.

Retrieving ozone in the boundary layer or even at the surface is of great interest for air quality monitoring. However, due to retrieval dependencies from other retrieval parameters, we cannot yet retrieve all the boundary layer ozone information available in OMI radiance spectra. To further improve the retrievals, we need to continue the improvement of instrumental calibration and perform more accurate radiative transfer simulations. Due to the extensive on-line radiative transfer calculations and large volume of OMI data, it is currently challenging to make retrievals available over the entire OMI period. We will continue to optimize radiative transfer calculations and use more computer resources to speed up the retrievals and make the OMI data record available to the scientific community in the near future.

Acknowledgements. This study was supported by the NASA Atmospheric Composition Program (NNG06GH99G), the New Investigator Program in Earth Science (NNX08AN98G), and the Smithsonian Institution. The Dutch-Finnish OMI instrument is part of the NASA EOS Aura satellite payload. The OMI Project is managed by NIVR and KNMI in the Netherlands. We acknowledge the OMI International Science Team and MLS science team for providing satellite data used in this study. NCEP Reanalysis data are provided by NOAA/OAR/ESRL PSD, Boulder, CO, USA, from their Web site at http://www.cdc.noaa.gov. We also thank J. Joiner, S. Taylor, and G. Jaross for discussions on OMI radiance calibration

Edited by: M. Van Roozendael

\section{References}

Acarreta, J. R., De Haan, J. F., and Stammes, P.: Cloud pressure retrieval using the $\mathrm{O}_{2}-\mathrm{O}_{2}$ absorption band at $477 \mathrm{~nm}$, J. Geophys. Res., 109, D05204, doi:10.1029/2003JD003915, 2004.

Auvray, M. and Bey, I.: Long-range transport to Europe: Seasonal variations and implications for the European ozone budget, J. Geophys. Res., 110, D11303, doi:10.1029/2004JD005503, 2005.

Bhartia, P. K., McPeters, R. D., Mateer, C. L., Flynn, L. E., and Wellemeyer, C.: Algorithm for the estimation of vertical ozone profiles from the backscattered ultraviolet technique, J. Geophys. Res., 101, 18793-18806, 1996.

Braak, R.: Bug fix for GDPS measurement noise calculation algorithm, KNMI, Technical Note TN-OMIE-KNMI-935, 2010.

Brion, J., Chakir, A., Daumont, D., and Malicet, J.: High-resolution laboratory absorption cross section of $\mathrm{O}_{3}$. Temperature effect, Chem. Phys. Lett., 213, 610-612, 1993.

Caspar, C. and Chance, K.: GOME wavelength calibration using solar and atmospheric spectra, Third ERS Symposium on Space at the Service of our Environment, Florence, Italy, 14-21 March, 609-614, 1997.

Chance, K.: Analysis of BrO measurements from the Global Ozone Monitoring Experiment, Geophys. Res. Lett., 25, 3335-3338, 1998.

Chance, K., Kurosu, T. P., and Sioris, C. E.: Undersampling correction for array detector-based satellite spectrometers, Appl. Opt., 44, 1296-1304, 2005.

Chance, K. V., Burrows, J. P., and Schneider, W.: Retrieval and molecule sensitivity studies for the Global Ozone Monitoring Experiment and the SCanning Imaging Absorption spectroMeter for Atmospheric CHartographY, P. Soc. Photo-Opt. Ins., 1491, $151-165,1991$.

Chance, K. V., Burrows, J. P., Perner, D., and Schneider, W.: Satellite measurements of atmospheric ozone profiles, including tropospheric ozone, from ultraviolet/visible measurements in the nadir geometry: a potential method to retrieve tropospheric ozone, J. Quant. Spectrosc. Ra., 57, 467-476, 1997.

Cooper, O., Forster, C., Parrish, D., Dunlea, E., Hübler, G., Fehsenfeld, F., Holloway, J., Oltmans, S., Johnson, B., Wimmers, A., and Horowitz, L.: On the life cycle of a stratospheric intrusion and its dispersion into polluted warm conveyor belts, J. Geophys. Res., 109, D23S09, doi:10.1029/2003JD004006, 2004a.

Cooper, O. R., Forster, C., Parrish, D., Trainer, M., Dunlea, E., Ryerson, T., Hübler, G., Fehsenfeld, F., Nicks, D., Holloway, J., de Gouw, J., Warneke, C., Roberts, J. M., Flocke, F., and Moody, J.: A case study of transpacific warm conveyor belt transport: Influence of merging airstreams on trace gas import to North America, J. Geophys. Res., 109, D23S08, doi:10.1029/2003JD003624, 2004b.

Cooper, O. R., Stohl, A., Hübler, G., Hsie, E. Y., Parrish, D. D., Tuck, A. F., Kiladis, G. N., Oltmans, S. J., Johnson, B. J., Shapiro, M., Moody, J. L., and Lefohn, A. S.: Direct transport of midlatitude stratospheric ozone into the lower troposphere and marine boundary layer of the tropical Pacific Ocean, J. Geophys. Res., 110, D23310, doi:10.1029/2005JD005783, 2005.

Cooper, O. R., Trainer, M., Thompson, A. M., Oltmans, S. J., Tarasick, D. W., Witte, J. C., Stohl, A., Eckhardt, S., Lelieveld, J., Newchurch, M. J., Johnson, B. J., Portmann, R. W., Kalnajs, L., Dubey, M. K., Leblanc, T., McDermid, I. S., Forbes, G., Wolfe, D., Carey-Smith, T., Morris, G. A., Lefer, B., Rappenglück, B., Joseph, E., Schmidlin, F., Meagher, J., Fehsenfeld, F. C., Keating, T. J., Van Curen, R. A., and Minschwaner, K.: Evidence for a recurring eastern North America upper tropospheric ozone maximum during summer, J. Geophys. Res., 112, D23304, doi:10.1029/2007JD008710, 2007.

Dobber, M. R., Dirksen, R. J., Levelt, P. F., van den Oord, G. H. J., Voors, R. H. M., Kleipool, Q., Jaross, G., Kowalewski, M., Hilsenrath, E., Leppelmeier, G. W., de Vries, J., Dierssen, W., and Rozemeijer, N. C.: Ozone Monitoring Instrument calibration, IEEE T. Geosci. Remote, 44, 1209-1238, 2006.

Duncan, B. N. and Bey, I.: A modeling study of the export pathways of pollution from Europe: Seasonal and interannual variations (1987-1997), J. Geophys. Res., 109, D08301, doi:10.1029/2003JD004079, 2004.

Edwards, D. P., Lamarque, J.-F., Attie, J.-L., Emmons, L. K., Richter, A., Cammas, J.-P., Gille, J. C., Francis, G. L., Deeter, M. N., Warner, J., Ziskin, D. C., Lyjak, L. V., Drummond, J. R., and Burrows, J. P.: Tropospheric ozone over the tropical 
Atlantic: A satellite perspective, J. Geophys. Res., 108, 4237, doi:10.1029/2002JD002927, 2003.

Froidevaux, L., Jiang, Y. B., Lambert, A., Livesey, N. J., Read, W. G., Waters, J. W., Browell, E. V., Hair, J. W., Avery, M. A., McGee, T. J., Twigg, L. W., Sumnicht, G. K., Jucks, K. W., Margitan, J. J., Sen, B., Stachnik, R. A., Toon, G. C., Bernath, P. F., Boone, C. D., Walker, K. A., Filipiak, M. J., Harwood, R. S., Fuller, R. A., Manney, G. L., Schwartz, M. J., Daffer, W. H., Drouin, B. J., Cofield, R. E., Cuddy, D. T., Jarnot, R. F., Knosp, B. W., Perun, V. S., Snyder, W. V., Stek, P. C., Thurstans, R. P., and Wagner, P. A.: Validation of Aura Microwave Limb Sounder stratospheric ozone measurements, J. Geophys. Res., 113, D15S20, doi:10.1029/2007JD008771, 2008.

Hasekamp, O. P. and Landgraf, J.: Ozone profile retrieval from backscattered ultraviolet radiances: The inverse problem solved by regularization, J. Geophys. Res., 106, 8077-8088, 2001.

Hasekamp, O. P. and Landgraf, J.: Tropospheric ozone information from satellite-based polarization measurements, J. Geophys. Res., 107, 4326, doi:10.1029/2001JD001346, 2002.

Herman, J. R. and Celarier, E. A.: Earth surface reflectivity climatology at 340-380 nm from TOMS data, J. Geophys. Res., 102, 28003-28011, 1997.

Hoogen, R., Rozanov, V. V., and Burrows, J. P.: Ozone profiles from GOME satellite data: Algorithm description and first validation, J. Geophys. Res., 104, 8263-8280, 1999.

Hudson, R. D., Kim, J.-H., and Thompson, A. M.: On the derivation of tropospheric column from radiances measured by the Total Ozone Mapping Spectrometer, J. Geophys. Res., 100, 1113711145, 1995.

Hudson, R. D., Frolov, A. D., Andrade, M. F., and Follette, M. B.: The total ozone field separated into meteorological regimes. Part I: defining the regimes, J. Atmos. Sci., 60, 1669-1677, 2003.

Jiang, Y. B., Froidevaux, L., Lambert, A., Livesey, N. J., Read, W. G., Waters, J. W., Bojkov, B., Leblanc, T., McDermid, I. S., Godin-Beekmann, S., Filipiak, M. J., Harwood, R. S., Fuller, R. A., Daffer, W. H., Drouin, B. J., Cofield, R. E., Cuddy, D. T., Jarnot, R. F., Knosp, B. W., Perun, V. S., Schwartz, M. J., Snyder, W. V., Stek, P. C., Thurstans, R. P., Wagner, P. A., Allaart, M., Andersen, S. B., Bodeker, G., Calpini, B., Claude, H., Coetzee, G., Davies, J., De Backer, H., Dier, H., Fujiwara, M., Johnson, B., Kelder, H., Leme, N. P., König-Langlo, G., Kyro, E., Laneve, G., Fook, L. S., Merrill, J., Morris, G., Newchurch, M., Oltmans, S., Parrondos, M. C., Posny, F., Schmidlin, F., Skrivankova, P., Stübi, R., Tarasick, D., Thompson, A., Thouret, V., Viatte, P., Vömel, H., von Der Gathen, P., Yela, M., and Zablocki, G.: Validation of Aura Microwave Limb Sounder Ozone by ozonesonde and lidar measurements, J. Geophys. Res., 112, D24S34, doi:10.1029/2007JD008776, 2007.

Joiner, J. and Aikin, A. C.: Temporal and spatial variations in upper atmospheric Mg, J. Geophys. Res., 101, 5239-5250, 1996.

Joiner, J. and Vasilkov, A. P.: First results from the OMI rotational raman scattering cloud pressure algorithm, IEEE T. Geosci. Remote, 44, 1272-1282, 2006.

Kalnay, E., Kanamitsu, M., Kistler, R., Collins, W., Deaven, D., Gandin, L., Iredell, M., Saha, S., White, G., Woollen, J., Zhu, Y., Chelliah, M., Ebisuzaki, W., Higgins, W., Janowiak, J., Mo, K. C., Ropelewski, C., Wang, J., Leetmaa, A., Reynolds, R., Jenne, R., and Joseph, D.: The NCEP/NCAR 40-year reanalysis project, B. Am. Meteorol. Soc., 77, 437-471, 1996.
Lelieveld, J., Berresheim, H., Bormann, S., Crutzen, P. J., Dentener, F. J., Fischer, H., Feichter, J., Flatau, P. J., Heland, J., Holzinger, R., Kormann, R., Lawrence, M. G., Levin, Z., Markowicz, K. M., Mihalopoulos, N., Minikin, A., Ramanathan, V., de Reus, M., Roelofs, G. J., Scheeren, H. A., Scaire, J., Schlager, H., Schultz, M., Siegmund, P., Steil, B., Stephanou, E. G., Stier, P., Traub, M., Warneke, C., Williams, J., and Ziereis, H.: Global air pollution crossroads over the Mediterranean, Science, 298, 794-798, 2002.

Levelt, P. F., van den Oord, G. H. J., Dobber, M. R., Malkki, A., Visser, H., de Vries, J., Stammes, P., Lundell, J. O. V., and Saari, H.: The Ozone Monitoring Instrument, IEEE T. Geosci. Remote, 44, 1093-1101, 2006.

Li, Q., Jacob, D., Park, R., Wang, Y., Heald, C., Hudman, R., Yantosca, R., Martin, R., and Evans, M.: North American pollution outflow and the trapping of convectively lifted pollution by upper-level anticyclone, J. Geophys. Res., 110, D10301, doi:10.1029/2004JD005039, 2005.

Liu, H., Jacob, D. J., Bey, I., Yantosca, R. M., Duncan, B. N., and Sachse, G. W.: Transport pathways for Asian pollution outflow over the Pacific: Interannual and seasonal variations, J. Geophys. Res., 108, 8786, doi:10.1029/2002JD003102, 2003.

Liu, X., Chance, K., Sioris, C. E., Spurr, R. J. D., Kurosu, T. P., Martin, R. V., and Newchurch, M. J.: Ozone profile and tropospheric ozone retrievals from Global Ozone Monitoring Experiment: Algorithm description and validation, J. Geophys. Res., 110, D20307, doi:10.1029/2005JD006240, 2005.

Liu, X., Chance, K., Sioris, C. E., Kurosu, T. P., and Newchurch, M. J.: Intercomparison of GOME, ozonesonde, and SAGE-II measurements of ozone: Demonstration of the need to homogenize available ozonesonde datasets, J. Geophys. Res., 101, D114305, doi:10.1029/2005JD006718, 2006a.

Liu, X., Chance, K., Sioris, C. E., Kurosu, T. P., Spurr, R. J. D., Martin, R. V., Fu, T. M., Logan, J. A., Jacob, D. J., Palmer, P. I., Newchurch, M. J., Megretskaia, I., and Chatfield, R. B.: First directly retrieved global distribution of tropospheric column ozone from GOME: Comparison with the GEOS-CHEM model, J. Geophys. Res., 111, D02308, doi:10.1029/2005JD006564, 2006 b.

Liu, X., Chance, K., Sioris, C. E., and Kurosu, T. P.: Impact of using different ozone cross sections on ozone profile retrievals from Global Ozone Monitoring Experiment (GOME) ultraviolet measurements, Atmos. Chem. Phys., 7, 3571-3578, 2007 , http://www.atmos-chem-phys.net/7/3571/2007/.

Liu, X., Bhartia, P. K., Chance, K., Froidevaux, L., Spurr, R. J. D., and Kurosu, T. P.: Validation of Ozone Monitoring Instrument (OMI) ozone profiles and stratospheric ozone columns with Microwave Limb Sounder (MLS) measurements, Atmos. Chem. Phys., 10, 2539-2549, 2010, http://www.atmos-chem-phys.net/10/2539/2010/.

Livesey, N. J., Filipiak, M. J., Froidevaux, L., Read, W. G., Lambert, A., Santee, M. L., Jiang, J. H., Pumphrey, H. C., Waters, J. W., Cofield, R. E., Cuddy, D. T., Daffer, W. H., Drouin, B. J., Fuller, R. A., Jarnot, R. F., Jiang, Y. B., Knosp, B. W., Li, Q. B., Perun, V. S., Schwartz, M. J., Snyder, W. V., Stek, P. C., Thurstans, R. P., Wagner, P. A., Avery, M., Browell, E. V., Cammas, J. P., Christensen, L. E., Diskin, G. S., Gao, R. S., Jost, H. J., Loewenstein, M., Lopez, J. D., Nédélec, P., Osterman, G. B., Sachse, G. W., and Webster, C. R.: Validation of Aura Microwave Limb Sounder $\mathrm{O}_{3}$ and $\mathrm{CO}$ observations in the upper tro- 
posphere and lower stratosphere, J. Geophys. Res., 113, D15S02, doi:10.1029/2007JD008805, 2008.

Logan, J. A., Megretskaia, I., Nassar, R., Murray, L. T., Zhang, L., Bowman, K. W., Worden, H. M., and Luo, M.: Effects of the 2006 El Nino on tropospheric composition as revealed by data from the Tropospheric Emission Spectrometer (TES), Geophys. Res. Lett., 35, L03816, doi:10.1029/2007GL031698, 2008.

Martin, R. V., Jacob, D. J., Logan, J. A., Bey, I., Yantosca, R. M., Staudt, A. C., Li, Q., Fiore, A. M., Duncan, B. N., Liu, H., Ginoux, P., and Thouret, V.: Interpretation of TOMS observations of tropical tropospheric ozone with a global model and in-situ observations, J. Geophys. Res., 107, 4351, doi:10.1029/2001JD001480, 2002.

McPeters, R. D., Labow, G. J., and Logan, J. A.: Ozone climatological profiles for satellite retrieval algorithms, J. Geophys. Res., 112, D05308, doi:10.1029/2005JD006823, 2007.

Meijer, Y. J., Swart, D. P. J., Baier, F., Bhartia, P. K., Bodeker, G. E., Casadio, S., Chance, K., Del Frate, F., Erbertseder, T., Felder, M. D., Flynn, L. E., Godin-Beekmann, S., Hansen, G., Hasekamp, O. P., Kaifel, A., Kelder, H. M., Kerridge, B. J., Lambert, J. C., Landgraf, J., Latter, B., Liu, X., McDermid, I. S., Pachepsky, Y., Rozanov, V., Siddans, R., Tellmann, S., van der A, R. J., van Oss, R. F., Weber, M., and Zehner, C.: Evaluation of Global Ozone Monitoring Experiment (GOME) ozone profiles from nine different algorithms, J. Geophys. Res., 111, D21306, doi:10.1029/2005JD006778, 2006.

Munro, R., Siddans, R., Reburn, W. J., and Kerridge, B.: Direct measurement of tropospheric ozone from space, Nature, 392, 168-171, 1998.

Parrish, D. D., Holloway, J. S., Trainer, M., Murphy, P. C., Forbes, G. L., and Fehsenfeld, F. C.: Export of North American ozone pollution to the North Atlantic Ocean, Science, 258, 1436-1439, 1993.

Rodgers, C. D.: Inverse methods for atmospheric sounding: Theory and practice, World Scientific Publishing, Singapore, 2000.

Sauvage, B., Thouret, V., Thompson, A. M., Witte, J. C., Cammas, J. P., Nédélec, P., and Athier, G.: Enhanced view of the "tropical Atlantic ozone paradox" and "zonal wave one" from the in situ MOZAIC and SHADOZ data, J. Geophys. Res., 111, D01301, doi:10.1029/2005JD006241, 2006.

Sauvage, B., Martin, R. V., van Donkelaar, A., and Ziemke, J. R.: Quantification of the factors controlling tropical tropospheric ozone and the South Atlantic maximum, J. Geophys. Res., 112, D11309, doi:10.1029/2006JD008008, 2007.

Schoeberl, M. R., Douglass, A. R., Hilsenrath, E., Bhartia, P. K., Beer, R., Waters, J. W., Gunson, M. R., Froidevaux, L., Gille, J. C., Barnett, J. J., Levelt, P. F., and de Cola, P.: Overview of the EOS Aura Mission, IEEE T. Geosci. Remote, 44, 1066-1074, 2006.

Schoeberl, M. R., Ziemke, J. R., Bojkov, B., Livesey, N., Duncan, B., Strahan, S., Froidevaux, L., Kulawik, S., Bhartia, P. K., Chandra, S., Levelt, P. F., Witte, J. C., Thompson, A. M., Cuevas, E., Redondas, A., Tarasick, D. W., Davies, J., Bodeker, G., Hansen, G., Johnson, B. J., Oltmans, S. J., Vömel, H., Allaart, M., Kelder, H., Newchurch, M., Godin-Beekmann, S., Ancellet, G., Claude, H., Andersen, S. B., Kyr, E., Parrondos, M., Yela, M., Zablocki, G., Moore, D., Dier, H., von der Gathen, P., Viatte, P., Stübi, R., Calpini, B., Skrivankova, P., Dorokhov, V., de Backer, H., Schmidlin, F. J., Coetzee, G., Fujiwara, M., Thouret, V., Posny,
F., Morris, G., Merrill, J., Leong, C. P., Koenig-Langlo, G., and Joseph, E.: A trajectory-based estimate of the tropospheric ozone column using the residual method, J. Geophys. Res., 112, D24S49, doi:10.1029/2007JD008773, 2007.

Sioris, C. E. and Evans, W. F. J.: Impact of rotational Raman scattering in the $\mathrm{O}_{2} \quad A$ band, Geophys. Res. Lett., 27, 4085-4088, 2000.

Spurr, R. J. D.: Simultaneous derivation of intensities and weighting functions in a general pseudo-spherical discrete ordinate radiative transfer treatment, J. Quant. Spectrosc. Ra., 75, 129-175, 2002.

Spurr, R. J. D.: LIDORT V2PLUS: a comprehensive radiative transfer package for UV/VIS/NIR nadir remote sensing, Society of Photo-Optical Instrumentation Engineers (SPIE) Conference Series, 1 February, 2004, 89-100, 2004.

Spurr, R. J. D.: VLIDORT: A linearized pseudo-spherical vector discrete ordinate radiative transfer code for forward model and retrieval studies in multilayer multiple scattering media, J. Quant. Spectrosc. Ra., 102, 316-342, 2006.

Spurr, R. J. D.: Linearized pseudo-spherical scalar and vector discrete ordinate radiative transfer models for use in remote sensing retrieval problems, in: Light Scattering Reviews, edited by: Kokhanovsky, A., Springer, New York, 2008.

Stajner, I., Wargan, K., Pawson, S., Hayashi, H., Chang, L.-P., Hudman, R. C., Froidevaux, L., Livesey, N., Levelt, P. F., Thompson, A. M., Tarasick, D. W., Stübi, R., Andersen, S. B., Yela, M., König-Langlo, G., Schmidlin, F. J., and Witte, J. C.: Assimilated ozone from EOS-Aura: Evaluation of the tropopause region and tropospheric columns, J. Geophys. Res., 113, D16S32, doi:10.1029/2007JD008863, 2008.

Thompson, A. M., Doddridge, B. G., Witte, J. C., Hudson, R. D., Luke, W. T., Johnson, J. E., Johnson, B. J., Oltmans, S. J., and Weller, R.: A tropical Atlantic paradox: Shipboard and satellite views of a tropospheric ozone maximum and wave-one in January-February 1999, Geophys. Res. Lett., 27, 3317-3320, 2000 .

van der A, R. J., van Oss, R. F., Piters, A. J. M., Fortuin, J. P. F., Meijer, Y. J., and Kelder, H. M.: Ozone profile retrieval from recalibrated GOME data, J. Geophys. Res., 107, 4239, doi:10.1029/2001JD000696, 2002.

van Oss, R. F., Voors, R. H. M., and Spurr, R. J. D.: Ozone profile algorithm, in: OMI Algorithm Theoretical Basis Document, Volume II: OMI ozone products, edited by: Bhartia, P. K., Greenbelt, MD, 51-73, 2001.

Worden, J., Liu, X., Bowman, K., Chance, K., Beer, R., Eldering, A., Gunson, M., and Worden, H. M.: Improved tropospheric ozone profile retrievals using OMI and TES radiances, Geophys. Res. Lett., 34, L01809, doi:10.1029/2006GL027806, 2007.

Zhang, L., Jacob, D. J., Boersma, K. F., Jaffe, D. A., Olson, J. R., Bowman, K. W., Worden, J. R., Thompson, A. M., Avery, M. A., Cohen, R. C., Dibb, J. E., Flock, F. M., Fuelberg, H. E., Huey, L. G., McMillan, W. W., Singh, H. B., and Weinheimer, A. J.: Transpacific transport of ozone pollution and the effect of recent Asian emission increases on air quality in North America: an integrated analysis using satellite, aircraft, ozonesonde, and surface observations, Atmos. Chem. Phys., 8, 6117-6136, 2008, http://www.atmos-chem-phys.net/8/6117/2008/. 